\title{
Granzyme B-induced apoptosis in cancer cells and its regulation (Review)
}

\author{
ILONA ROUSALOVA ${ }^{1}$ and EVZEN KREPELA ${ }^{1,2}$ \\ ${ }^{1}$ Laboratories of Molecular and Cell Biology, Department of Pneumology and Thoracic Surgery, University Hospital Bulovka; \\ ${ }^{2}$ Institute of Medical Biochemistry, 1st Faculty of Medicine, Charles University in Prague, Prague, Czech Republic
}

Received July 29, 2010; Accepted September 3, 2010

DOI: 10.3892/ijo_00000788

\begin{abstract}
The granzyme B-induced cell death has been traditionally viewed as a primary mechanism that is used by cytotoxic T lymphocytes (CTLs) and natural killer (NK) cells to eliminate harmful target cells including allogeneic, virally infected and tumour cells. Granzyme B (GrB) is the most abundant serine protease which is stored in secretory granules of CTLs and NK cells. After recognition of the target cell, the engaged CTLs and NK cells vectorially secrete GrB along with other granule proteins including perforin into the immunological synapse. From this submicroscopic intercellular cleft GrB translocates into the cytoplasm of the target cell. Although several models have been proposed to explain the GrB delivery mechanism, conclusive understanding of this process remains still elusive. Once in the cytoplasm, GrB cleaves and activates, or inactivates, multiple protein substrates, resulting eventually into apoptotic demise of the target cell. This review is focused on the gene structure and expression of $\mathrm{GrB}$, its biosynthesis and activation, delivery mechanisms into the target cell cytoplasm, direct proteolytic involvement in activation of several pro-apoptotic pathways, and on regulation of its activity in cancer cells. Moreover, emphasis is given to the GrB-mediated anticancer effects and future clinical applications of the GrB-based and tumour-targeted recombinant fusion constructs.
\end{abstract}

\section{Contents}

1. Introduction

2. Granzyme B gene organization and regulation of expression

3. Granzyme B biosynthesis, subcellular localization and activation

4. Granzyme B structure and substrate specificity

Correspondence to: Dr Evzen Krepela, Department of Pneumology and Thoracic Surgery, University Hospital Bulovka, Budinova 2, 18081 Prague 8, Czech Republic

E-mail: enkre@seznam.cz

Key words: cancer cells, apoptosis, granzyme B, perforin, serpinB9, proteinase inhibitor-9
5. Granzyme B delivery mechanism into the target cell cytoplasm

6. Death pathways activated by granzyme B in cancer cells

7. Regulation of granzyme B activity

8. Granzyme B and anticancer therapy

9. Conclusion and the future directions of research

\section{Introduction}

Susceptibility of tumour cells to apoptotic death depends on their capabilities to express the components of apoptosis pathways and to activate them in response to extrinsic or intrinsic death signals. The extrinsic death pathways are represented by the death receptor- and the cytotoxic granulemediated pathways. On the other hand, the intrinsic death mechanisms are represented by the mitochondrial, lysosomal and PIDDosome death pathways.

The death receptor pathway is triggered by the binding of a death ligand, such as FasL (also known as CD95L) and TRAIL (also known as APO-2L) to a specific transmembrane death receptors, Fas (also known as APO-1/CD95) and death receptor 4 and/or 5 (DR4, DR5), respectively $(1,2)$. After binding of the cytosolic Fas-associated death domain adaptor protein (FADD, also known as MORT1) to the liganded death receptors, the initiator procaspase- 8 and/or -10 are bound to engaged FADD completing the formation of the deathinducing signalling complexes (DISCs) (1-4). Within DISCs, procaspase- 8 and -10 are activated via homodimerization and the active caspase- 8 and -10 , arising through interdimer proteolytic processing, dissociate from DISCs into the cytoplasm where they cleave and activate procaspase- 3 and $-7(1,2,5,6)$. In addition, both caspase- 8 and -10 also cleave the cytosolic $\mathrm{BH} 3$-interacting domain death agonist (Bid) protein $(7,8)$. The C-terminal fragment, $\mathrm{t}(\mathrm{c}) \mathrm{Bid}$, which is formed binds to mitochondria, induces efflux of mitochondrial holocytochrome-c (cyt-c) and other pro-apoptotic mitochondrial proteins into the cytoplasm (9).

The mitochondrial pathway is launched in response to a variety of death stimuli such as DNA damage, chemotherapeutic agents or ultraviolet (UV) light. In these instances, the pro-apoptotic proteins Bax or Bak mediate mitochondrial outer membrane permeabilization (MOMP) and release several pro-apoptotic intermembrane mitochondrial proteins such as cyt-c, second mitochondria-derived activator of caspases (Smac), high temperature requirement A2 (HtrA2)/ 
Omi serine protease, apoptosis inducing factor (AIF) and endonuclease-G (Endo-G) (10-12). In the presence of dATP or ATP, cyt-c binds to apoptotic protease-activating factor-1 (Apaf-1) and induces its oligomerization into a large heptameric complex called apoptosome (13-15). The apoptosome recruits and activates procaspase-9 (16-19). The active apoptosome-bound caspase- 9 then activates the zymogens of the apoptotic effector caspase-3 and -7 (20-22). Both Smac and HtrA2 neutralize the anti-apoptotic functions of the inhibitor of apoptosis proteins (IAPs) $(12,23)$, whereas AIF and Endo-G, after translocation into the cell nucleus, are involved in DNA fragmentation $(10,24)$.

Activation of procaspase-2, an another apoptotic initiator, proceeds within a specific activation multiprotein complex called PIDDosome (25-27). In response to various cellular stresses, this complex can be inducibly formed in the cytoplasm and/or in the cell nucleus $(27,28)$. The PIDDosome assembled in the cytosol is build of three layers of homooligomerized proteins. The proteins are an autoproteolytic carboxyterminal fragment of the p53-induced protein with a death domain (PIDD-CC), the receptor interacting protein (RIP)-associated ICH-1/CED-3 homologous protein with a death domain (RAIDD), and procaspase-2 $(26,28,29)$. The PIDDosome assembled in the nucleus is composed of PIDD$\mathrm{C}$ and/or PIDD-CC, the catalytic subunit of DNA-dependent protein kinase $\left(\mathrm{DNA}-\mathrm{PK}_{\mathrm{CS}}\right.$ ) and procaspase-2 (27). After release from the RAIDD-PIDDosome, the active caspase-2 cleaves the BH3-only protein Bid, leading to MOMP, and other protein substrates including Golgin 160, DNA fragmentation factor subunit A and some cytoskeletal proteins $(30,31)$.

Apoptotic stimuli, such as oxidative stress, tumour necrosis factor (TNF)- $\alpha$ treatment, lysosomotropic agents, sphingosines, etoposide, UV light, FasL or TRAIL have been shown to trigger lysosomal membrane permeability (32-34). The partial release of some cathepsins including $\mathrm{B}, \mathrm{K}, \mathrm{L}$, and $\mathrm{S}$ into the cytoplasm results in proteolytic fragmentation of Bid protein and release of cyt-c from the $\mathrm{t}(\mathrm{c}) \mathrm{Bid}$-disrupted mitochondria (35-37).

Both the intrinsic and the extrinsic apoptosis pathways converge on the activation of the effector apoptotic procaspase- $3,-6$, and $-7(22,34,38,39)$ as well as they lead to MOMP via cleavage of Bid protein and/or the Mcl-1 protein component of the Mcl-1•Bim complex (7,40-44).

The present review is focused on the role of the serine proteinase granzyme B $(\mathrm{GrB})$ in the cytotoxic granulemediated apoptosis pathway, which is thought to be the most important mechanism for clearance of cells infected with intracellular pathogens, allogeneic cells and tumour cells (45-49). After the cell recognition-based conjugation of cytotoxic T lymphocytes (CTLs) and natural killer (NK) cells with their target cells, the cytotoxic secretory granules of CTLs and NK cells are vectorially transported towards the conjugation zone and their content is released into a submicroscopic intercellular cleft called immunological synapse (IS) $(50,51)$. The most abundant components of cytotoxic granules are $\mathrm{GrB}$ and the pore-forming protein perforin (PFN). $\mathrm{GrB}$ is considered to be a major effector of target cell killing by NK cells (52). In addition, the cytotoxic granules of human CTLs and NK cells contain also other granzymes (A, $\mathrm{H}, \mathrm{K}$ and $\mathrm{M}$ ), which may co-deliver alternative death signals that operate independently of procaspases activation and MOMP induction $(47,52,53)$. The precise mechanism of GrB translocation into the target cell is not known. Once in the target cell cytoplasm, GrB can trigger several apoptotic pathways via direct proteolytic activation of their signalling or executioner components and itself cleaves multiple intracellular housekeeping proteins (Fig. 1).

Many topics regarding the intracellular versus extracellular role of GrB in immunity and autoimmunity have been recently reviewed (53-58). In the present article, we review the gene structure and expression of $\mathrm{GrB}$, its biosynthesis and activation, delivery mechanisms into the target cell cytoplasm, and engagement in activation of several pro-apoptotic pathways. Special attention is given to the regulation of GrB proteolytic activity in human cancer cells of solid tumours. Furthermore, we also discuss the promising clinical applications of the GrB-based tumour-targeted therapy, alone or in combination with other anti-tumour treatment.

\section{Granzyme B gene organization and regulation of expression}

The human GrB gene (GZMB) was mapped to the 'chymase locus' on chromosome 14q11.2 (59). This locus contains other three functional genes: granzymes $\mathrm{H}$ gene $(G Z M H)$, cathepsin $\mathrm{G}$ gene (CTSG), and mast cell chymase gene (CMA1). GZMB gene is located at the 5 ' end of the cluster, followed by GZMH, CTSG, and CMAl genes (60). GZMB gene is approximately $3.2 \mathrm{~kb}$ in length and is composed of five exons and four introns (61). The leader (signal) sequence of $\mathrm{GrB}$ preproprotein is encoded by exon I, the amino acid residues forming the catalytic triad, i.e., $\mathrm{His}^{57}$, $\mathrm{Asp}^{102}$, and $\mathrm{Ser}^{195}$, are encoded within the exons II, III and V, respectively (62).

Studies of the GZMB promoter revealed that it contains consensus sequences for binding of several transcription factors, including nuclear factor of activated T cells (NFAT), Ikaros and activator protein-1 (AP-1) $(63,64)$. Recently, a

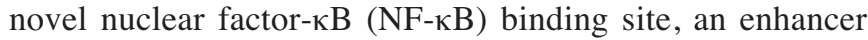
element, responsible for activation of $G Z M B$ gene transcription in NK cells has been identified outside of the GZMB gene, approximately $10 \mathrm{~kb}$ downstream from its transcription start point (65). Interestingly, interleukin-3 (IL-3) plays a crucial role in inducible $\mathrm{GrB}$ expression in human plasmacytoid dendritic cells and the expression of $\mathrm{GrB}$ is regulated on the transcriptional level involving Janus kinase 1 (JAK1) and signal transducer and activator of transcription (STAT) 3 and STAT5 (66).

GZMB gene polymorphism has been described in a genetic screen of individuals from various racial groups (67). Compared to the wild-type QPY allele of GZMB gene encoding GrB preproprotein with $\mathrm{Gln}^{48}$, $\mathrm{Pro}^{90}$, and $\mathrm{Tyr}^{247}$ in its sequence, the RAH allele of $G Z M B$ gene encodes GrB preproprotein containing $\mathrm{Arg}^{48}, \mathrm{Ala}^{90}$, and $\mathrm{His}^{247}$ (67). The RAH allele occurs at a frequency rate of $25-30 \%$ in each of the racial groups studied and it was proven to represent a neutral GZMB gene polymorphism (68).

Initially, it was thought that the GrB expression is restricted to lymphoid cells $(45,69,70)$. However, under certain pro-inflammatory conditions, for instance at a particular 


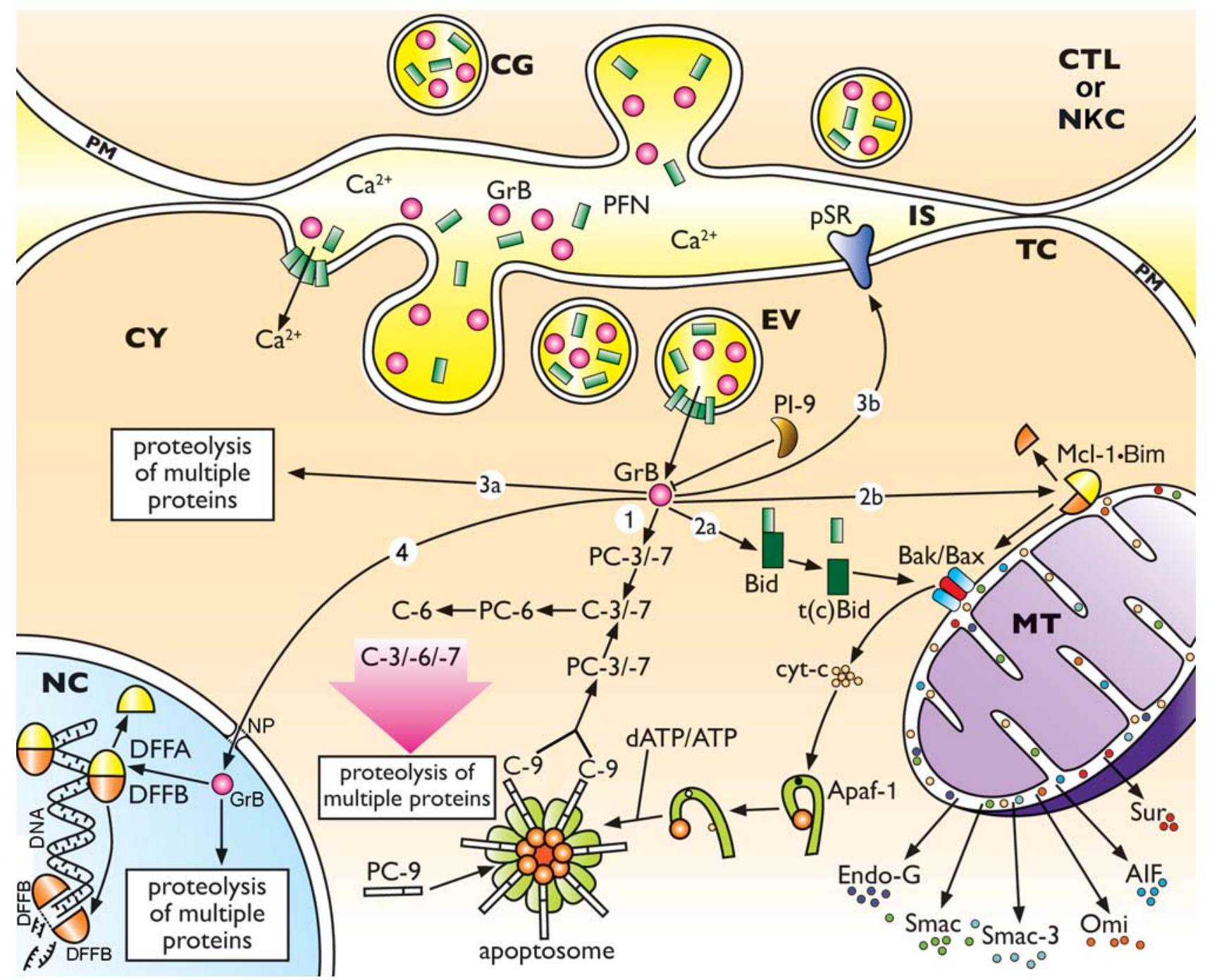

Figure 1. Granzyme B-induced death pathways in cancer cells. [1], Direct proteolytic processing and activation of the executioner procaspase-3 and -7, followed by the caspase-3-mediated activation of the executioner procaspase-6. The active executioner caspases cleave many intracellular proteins. [2], Mitochondrial outer membrane permeabilization (MOMP) via the GrB-mediated proteolytic [2a] conversion and activation of protein Bid to the MOMP-inducing $\mathrm{t}(\mathrm{c}) \mathrm{Bid}$ fragment, and [2b] disruption of the Bim॰Mcl-1 complex, involving fragmentation of the Mcl-1 component, and hence derepression of the MOMP-activity of Bim, followed by cytosolic release of several pro-apoptotic proteins (cyt-c, Smac, Smac-3, Omi/HtrA2, AIF and Endo-G) and the inhibitor-of apoptosis protein survivin (Sur). [3a], Proteolytic fragmentation of multiple housekeeping proteins in the cytoplasm (Table I), including [3b] the cytosol-facing signalling domains of some pro-survival plasma membrane receptors (pSR). [4], Translocation into the nucleus and proteolytic fragmentation of multiple intranuclear proteins (Table I), including the DFFA subunit of DNA fragmentation factor (DFFA•DFFB), which leads to the homodimerization-mediated activation of its deoxyribonuclease subunit DFFB. See the text for a more detailed description. CTL, cytotoxic lymphocyte; NKC, natural killer cell; CG, cytotoxic granule; IS, immunological synapse; PM, plasma membrane; TC, target cell; EV, endocytic vesicle; CY, cytoplasm; MT, mitochondrion; NC, nucleus; NP, nuclear pore; PC, procaspase; C, caspase.

composition of the extracellular cytokine milieu, the nature of various receptors engagement, and the presence of regulatory CD4 ${ }^{+} \mathrm{T}$ cells, GrB can be expressed not only in normal cells of haematopoietic origin, such as $\mathrm{CD} 4^{+} \mathrm{T}$ cells, mast cells, activated macrophages and Kupffer cells, neutrophils, basophils and dendritic cells, but also in normal cells of non-haematopoietic origin, including chodrocytes, keratinocytes, type II pneumocytes, Sertoli cells, primary spermatocytes, and cells of granulosa and syncytiotrophoblast (71-87).

Interestingly, GrB has been detected in cancer cells of primary human breast carcinomas $(88,89)$, lung carcinomas (88), urothelial carcinomas (90) and in nasal-type NK/T-cell lymphoma (91). Recently, GrB expression was revealed by immunohistochemistry in oral squamous cell carcinoma and it seems to be localized also in cancer cells (92). Considering these observations, we analysed the expression status of $\mathrm{GrB}$ mRNA in non-small cell lung carcinoma (NSCLC) cell lines and NSCLC tumours and matched lungs from surgically treated patients using uncoupled real-time RT-PCR. All examined NSCLC cell lines expressed GrB mRNA but its level was quite low and variable (Fig. 2A). However, compared to NSCLC cell lines, the expression of GrB mRNA in NSCLC tumours was substantially higher (Fig. 2B). In addition, there was no statistically significant difference in the GrB mRNA expression in NSCLC tumours and matched lungs (Fig. 2B) (Krepela et $a l$, unpublished data). These results indicate that the lung cancer cells themselves are not the major source of GrB expression in the lung tumours. This notion is further supported by undetectable expression of endogenous GrB protein in NSCLC cell lines (93). 

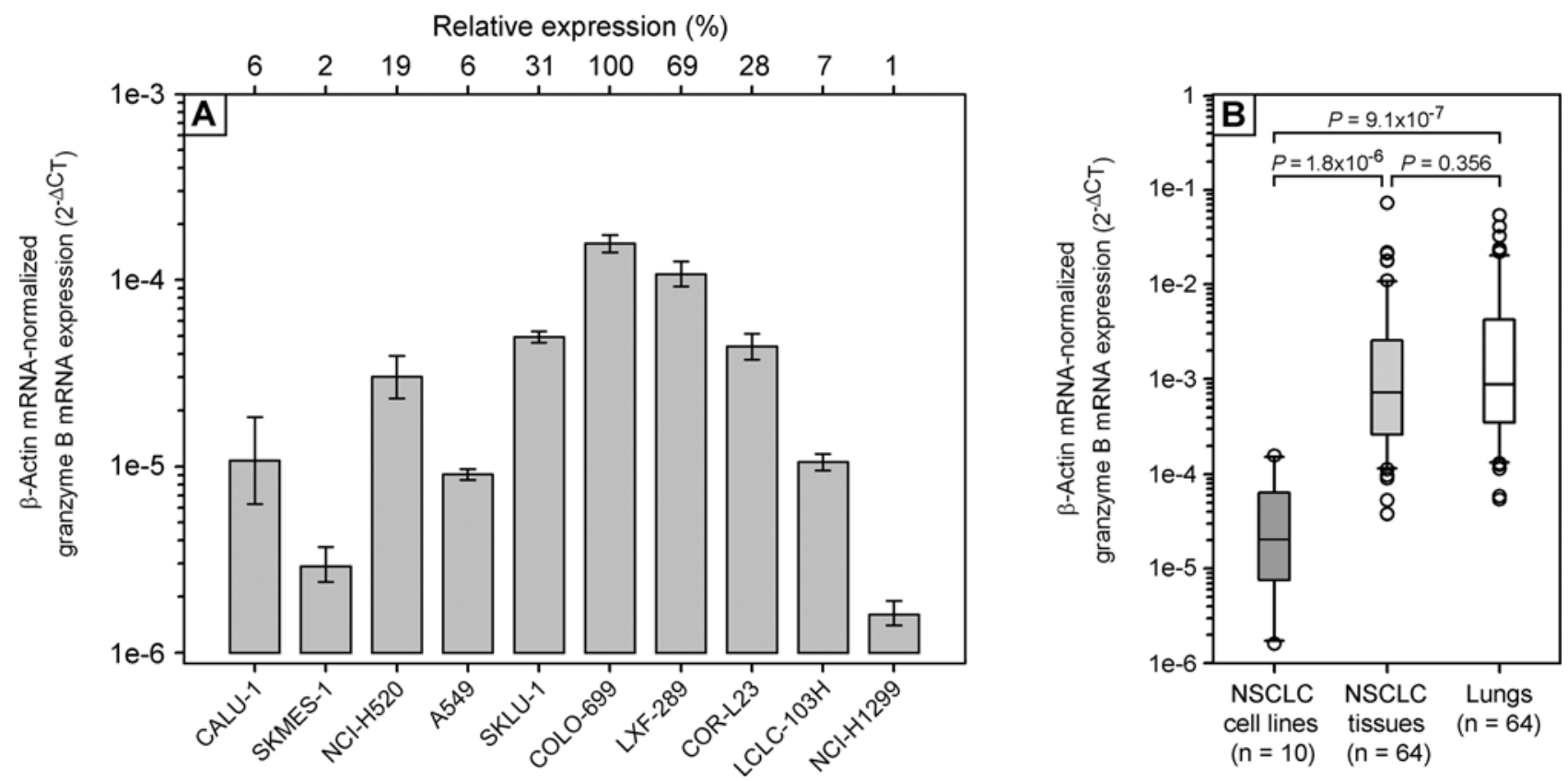

Figure 2. Expression of granzyme B mRNA in non-small cell lung carcinoma (NSCLC) cell lines and NSCLC tissues and lungs as analysed by uncoupled real-time RT-PCR. The sequences of the forward primer, the reverse primer, and the fluorogenic TaqMan probe used for quantification of granzyme B mRNA expression were, respectively: 5'-CTACTGCAGCTGGAGAGAAAGG-3', 5'-CAGCCGGCCACACTGCATGTCT-3', and 5'-(6FAM)GTACTGTCGTAA TAATGGCGTAAGTC(TAMRA)-3'. The sequences of the forward primer, the reverse primer, and the fluorogenic TaqMan probe used for quantification of B-actin mRNA (an endogenous reference transcript) expression were, respectively: 5'-CTGGCACCCAGCACAATG-3', 5'-GGGCCGGACTCGTCATAC-3', and 5'-(VIC)AGCCGCCGATCCACACGGAGT(TAMRA)-3'. (A), Relative levels of expression of B-actin mRNA-normalized granzyme B mRNA in NSCLC cell lines. Data indicated as mean \pm SEM from three independent experiments. (B), Comparison of the B-actin mRNA-normalized granzyme B mRNA expression in NSCLC cell lines and NSCLC tissues and matched lungs from surgically treated patients. In the box plot, the upper and the lower boundary of the box and the line within the box indicate the 75th and 25th percentiles and the median, respectively. The error bars above and below the box indicate the 90th and 10th percentiles. Statistical difference (P) between the granzyme B mRNA expression levels was calculated by Mann-Whitney test.

\section{Granzyme B biosynthesis, subcellular localization and activation}

Human preproGrB mRNA was first identified in 1987 (94) and one year later human GrB cDNA was cloned $(95,96)$. The human GrB protein was first purified and characterized in 1991 (97). GrB and other known human granzymes (A, H, K and $\mathrm{M}$ ) as well as the closely related myeloid serine proteases, such as cathepsin $\mathrm{G}$, are members of the chymotrypsin superfamily. Like other granzymes, GrB is synthesised as a preproenzyme while its signal peptide (i.e., the 18 amino acid residues long $\mathrm{N}$-terminal pre-part), directing the nascent polypeptide chain of the protein into the endoplasmatic reticulum (ER), is removed co-translationally. The resulting proGrB, covalently modified with a mannose-6-phosphate (M6P) group, is transported in ER-derived vesicles to the Golgi apparatus (GA) $(62,99)$. In GA, the M6P moiety serves for sorting out and targeting proGrB and other progranzymes to the GA-derived secretory granules (99). Once inside the secretory granules, proGrB is primarily activated by removal of the N-terminal dipeptide GlyGlu by co-segregated dipeptidyl peptidase I (DPPI; cathepsin C) $(62,98,100,101)$. Failure to remove the GlyGlu propeptide would disrupt the formation of the GrB catalytic site. Besides the major mode of proGrB activation by DPPI, there are other less defined mechanisms of proGrB proteolytic activation (102-104). Recently, the lysosomal cathepsin $\mathrm{H}$ was identified as another activator of proGrB (105).
Within the secretory granules, granzymes are stored in association with the chondroitin sulphate containing proteoglycan serglycin (SG) (106-109). Hitherto evidence suggests that the active granzymes are secreted in a macromolecular complex with SG during the target cell killing (106-109). Characterization of interaction between GrB and $\mathrm{SG}$ within granules revealed $\mathrm{GrB} \bullet \mathrm{SG}$ complexes of two distinct molecular sizes. One of them holds approximately 4-8 molecules of $\mathrm{GrB}$, whereas the other one contained as many as 32 molecules of $\mathrm{GrB}$ or other granule proteins (108). Storage of $\mathrm{GrB}$ in a scaffolded form in the acidic interior of the secretory granules might minimize the proteolytic activity of GrB $(108,109)$. The GrB molecule alone has a high positive surface charge, but when GrB binds to SG its charge may be substantially neutralized. Therefore, the free GrB molecule differs from the SG-bound GrB in that the former might interact with various negatively charged groups exposed on the cell surface, including phospholipid headgroups and those in glycosaminoglycans.

The newly synthesised GrB is heterogeneously glycosylated. The mature enzyme has two potential glycosylation sites at $\mathrm{Asn}^{51}$ and $\mathrm{Asn}^{84}$, where $\mathrm{N}$-linked oligosaccharide chains can be attached (110). The process of GrB glycosylation results in generation of both the 32 and $35 \mathrm{kDa}$ glycosylated forms of $\mathrm{GrB}$. The $32 \mathrm{kDa} \mathrm{GrB}$ forms contain high mannose oligosaccharide moieties and accumulate in CTLs after $\mathrm{T}$ cell receptor (TCR) stimulation (111). Hence, these forms can be stored in the CTLs secretory granules. In contrast, the $35 \mathrm{kDa}$ 
GrB forms, which possess only the complex oligosaccharide groups, are not stored in CTLs and instead they are secreted through the constitutive and less specific calcium-independent secretory pathway after TCR activation (111). When a CTL recognizes its target via the TCR, two events occur: the vectorial exocytosis of the secretory granules towards the IS, and the de novo biosynthesis of the lytic proteins, including granzymes and PFN.

\section{Granzyme B structure and substrate specificity}

$\mathrm{GrB}$ is a single chain and single domain serine protease. The crystal structure of human GrB was recently determined and provides some rationale for the substrate specificity of $\mathrm{GrB}$ $(112,113)$. The GrB structure is folded into two six-stranded B-barrels, which are connected by three trans-domain segments. The regular secondary structure elements include a helical loop between $\mathrm{Ala}^{56}$ and $\mathrm{Cys}^{58}$, a helix involving residues from $\mathrm{Asp}^{165}$ to $\mathrm{Leu}^{172}$, and a long C-terminal helix from $\mathrm{Phe}^{234}$ to $\mathrm{Arg}^{244}$. The peptide bond between $\mathrm{Pro}^{224}$ and $\mathrm{Pro}^{225}$ is in the cis conformation. The cis-conformation of these proline residues orients the positively charged $\operatorname{Arg}^{226}$ side chain into the S1 subsite (113).

Similar to caspases, GrB has a preference for cleaving peptide bonds immediately adjacent to Asp residues (97). This specificity is due to the structure of the GrB active site, which contains $\mathrm{Arg}^{226}$ residue in the S1 subsite. By the combinatorial chemistry approach, the tetrapeptide sequence IEPD has been identified as the preferred P4-P3-P2-P1 recognition motif of $\mathrm{GrB}$ for small peptide substrates, although optimal susbstrate recognition may involve features beyond this tetrapeptide sequence (113-116). Recent data indicate that $\mathrm{GrB}$ requires an extended substrate sequence, corresponding to the P4-P4' positions, for specific and efficient binding of protein substrates (116).

\section{Granzyme B delivery mechanism into the target cell cytoplasm}

How granzymes gain entry into the cytosol of target cells during killer cells attack has been subject of several studies in the past, but the effective delivery mechanism during target cell encounter has not been clarified so far. Upon formation of IS, a temporary intercellular conjugation zone, the lytic granules rapidly move and polarize towards the IS where the granzymes and PFN are subsequently released $(50,51)$. The movement of lytic granules within CTLs towards the target cells is directional and depends on an underlying $\mathrm{Ca}^{2+}$-activated microtubule cytoskeleton and other less defined $\mathrm{Ca}^{2+}$-required molecular events (117). Once arrived at the site of secretion, the membrane of secretory granules fuses with the plasma membrane and their content is discharged into a secretory cleft of IS. The IS functions as a conduit for the transportation of lytic granules content and other soluble factors between the CTLs and the target cell (118). It is still broadly debated whether granzymes enter the target cell cytoplasm through PFN pores formed at the post-synaptic plasma membrane or whether both granzymes and PFN are first endocytosed and the granzymes are subsequently released from endosomes within the cytoplasm $(107,119-132)$.
Granzyme B secretion. The exact mechanism of granzyme release from CTLs and NK cells into the extracellular environment remain enigmatic, but it is likely to involve several mechanisms. The lymphokine activated killer (LAK) cells stimulated to undergo granule exocytosis by phorbol myristic acetate and anti-CD2 monoclonal antibodies released GrB as a neutral, high macromolecular weight complex, which possessed pro-apoptotic activity (106). As a single CTL can kill multiple target cells, it is conceivable that free granzymes may leak from the immunological synapse during a CTL degranulation and moving to another target during serial killing $(111,133)$. Extracellular granzymes may also originate from constitutive non-specific secretion that is observed after TCR activation and/or prolonged exposure to interleukin-2 $(111,134)$. TCR triggering induces de novo granzyme synthesis, and it is thought that a proportion of newly synthesized GrB is non-specifically secreted through a nonvectorial pathway. This is due to the absence of accessible mannose-6-phosphate in the glycan moiety of the secreted GrB which cannot be targeted to the lytic granules via the mannose-6-phosphate receptor (111). It was recently found that a portion of GrB secreted into the IS can be recovered back into NK cells via clathrin-dependent endocytosis (135).

In the absence of target cell engagement, a proportion of GrB is constitutively secreted by both CTLs and NK cells. In NK cells, the protease is primarily released in an active form through secretory granules, whereas CTLs primarily secrete inactive GrB zymogen, bypassing the granules (133). To date, it is not known whether the secreted proGrB can be proteolytically converted to the active GrB. There is a possibility that an active DPPI and/or cathepsin $\mathrm{H}$, co-secreted by the CTLs or other adjacent cells, might remove the activation GlyGlu dipeptide en bloc. In addition to that, two sequentially acting aminopeptidases might remove the amino acid residues of the N-terminal dipeptide in a step-by-step fashion.

Mechanism of granzyme B internalization into target cells. How granzymes and perforin enter target cells in not fully understood. Several earlier studies provided evidence that $\mathrm{GrB}$ can be taken up first into the endosomal compartment of the cell, but that PFN (or other endosomolytic agent) coentry is necessary for its translocation into the cytoplasm and the cell nucleus (120-123).

It has been demonstrated that GrB binds to the target cell surface in the concentration-dependent and saturable manners and enters the cells via endocytosis (120). This GrB receptor-mediated endocytosis model has been further refined with the identification of the cation-independent mannose-6-phosphate receptor (CI-MPR) as a plasma membrane receptor for $\mathrm{GrB}(124,129,136)$. The process of the CI-MPR-mediated GrB internalization is clathrin and dynamin-dependent $(124,137)$. Recently, it has been showed that PFN triggers a wounded plasma membrane-repair response, which is the clathrin and dynamin-dependent endocytosis and which removes PFN and granzymes from the plasma membrane to early endosomes $(126,132)$. Several groups have proposed alternative mechanisms of GrB receptormediated cell entry, e.g., via CD44 molecules with known affinity for serglycin (138) or via Hsp70 which can serve as a GrB receptor (139). 
Table I. Granzyme B protein substrates.

\begin{tabular}{|c|c|c|c|c|}
\hline Protein & Function & Localization & Cleavage sites & Refs. \\
\hline Acetylcholine receptor $\varepsilon$ subunit $(\mathrm{AchR} \varepsilon)$ & Acetylcholine receptor & Plasma membrane & IDID $^{195}$ & $(266)$ \\
\hline Muscarinic acethylcholine receptor 3 (M3R) & Acethylcholine receptor & Plasma membrane & $\mathrm{MDQD}^{330}, \mathrm{PSSD}^{387}$ & $(277)$ \\
\hline B-Actin & Structural protein & Cytosol & $\mathrm{ND}^{\mathrm{a}}$ & $(267,268)$ \\
\hline Alanyl tRNA synthetase (ARS) & Translation & Cytosol & VAPD $^{632}$ & $(269)$ \\
\hline Bcl-2-associated athanogene 1 (Bag-1L) & Co-chaperone & Nucleus, cytosol & VTRD $^{125}, V_{V Q D}{ }^{172}$ & $(193)$ \\
\hline Bid & Pro-apoptotic sensor & Cytosol & IEAD $^{75}$ & $(166,270)$ \\
\hline CD3 & Signal tranducer & Plasma membrane & Many & $(274)$ \\
\hline Centromere protein B (CENP-B) & Mitosis & Nucleus & VDSD $^{457}$ & $(269,275)$ \\
\hline Centromere protein C (CENP-C) & Mitosis & Nucleus & ND & $(269)$ \\
\hline $\begin{array}{l}\text { DNA-dependent protein kinase } \\
\text { catalytic subunit (DNA-PKcs) }\end{array}$ & DNA repair & Nucleus & VGPD $^{2698}$ & $(269,276)$ \\
\hline DNA ligase IV/XRCC4 & DNA repair & Nucleus & $\mathrm{SKDD}^{254}$ & $(284)$ \\
\hline Fibrillarin & rRNA processing & Nucleolus & VGPD $^{184}$ & $(269)$ \\
\hline $\begin{array}{l}\text { Fibroblast growth factor receptor-1 } \\
\text { (FGFR-1) }\end{array}$ & FGFs receptor & Plasma membrane & ND & $(190)$ \\
\hline Filamin & Cytoskeletal protein & Cytosol & Many & $(186)$ \\
\hline Focal adhesion kinase (FAK) & Signal transducer & Cytosol & $\mathrm{VSWD}^{704}, \mathrm{DQTD}^{772}$ & $(285)$ \\
\hline$\alpha$-Fodrin & Cytoskeletal protein & Cytosol & IVTD $^{1554}$, AEID $^{1961}$ & $(187,277)$ \\
\hline Glutamate receptor subunit 3 (GluR3B) & Glutamate receptor & Plasma membrane & ISND $^{388}$ & $(280)$ \\
\hline Hip & Chaperone & Cytosol & IEPD $^{92}$, INPD $^{180}$ & $(192,193)$ \\
\hline Histidyl tRNA synthetase (HRS/Jo-1) & Translation & Cytosol & LGPD $^{48}$ & $(269,278)$ \\
\hline Hop & Protein folding & Cytosol & $\mathrm{LGVD}^{186}$ & $(191)$ \\
\hline Hsp27 & Protein folding & Cytosol & VSLD $^{100}$ & $(193)$ \\
\hline Hsp70 & Protein folding & Cytosol & $\mathrm{INPD}^{366}$ & $(190)$ \\
\hline Hsp90a & Protein folding & Cytosol & Many & $(193)$ \\
\hline Hsp90ß & Protein folding & Cytosol & Many & $(193)$ \\
\hline Isoleucyl tRNA synthetase & Translation & Cytosol & VTPD $^{983}$ & $(269)$ \\
\hline Ki-67 & Proliferation & Nucleus & VCTD $^{1481}$ & $(269)$ \\
\hline $\mathrm{Ku}-70$ & DNA repair & Nucleus & ISSD $^{79}$ & $(269)$ \\
\hline $\mathrm{La} / \mathrm{SSB}$ & RNA binding & Nucleus & LEED $^{220}$ & $(269)$ \\
\hline Lamin B & Structural protein & Nuclear lamina & $\mathrm{VEVD}^{231}$ & $(189)$ \\
\hline Mi-2 & $\begin{array}{l}\text { DNA methylation, } \\
\text { chromatin remodeling }\end{array}$ & Nucleus & VDPD $^{1312}$ & $(269,276)$ \\
\hline Mcl-1 & Inhibition of $\mathrm{MOMP}^{\mathrm{b}}$ & $\begin{array}{l}\text { Mitochondrial } \\
\text { outer membrane }\end{array}$ & $\begin{array}{l}\text { PAAD }^{117}, \text { EELD }^{127} \\
\text { TSTD }^{157}\end{array}$ & $(41)$ \\
\hline Notch1 & $\begin{array}{l}\text { Delta-like and Serrate- } \\
\text { like ligands receptor }\end{array}$ & Plasma membrane & ND & $(190)$ \\
\hline Nuclear mitotic apparatus protein 1 (NuMa) & Mitosis & Nucleus & VATD $^{1705}$ & $(269,276)$ \\
\hline $\begin{array}{l}\text { Nucleolus organizing region } 90 \mathrm{kDa} \\
\text { (NOR-90/UBF) }\end{array}$ & Transcription factor & Nucleolus & ND & $(269)$ \\
\hline Nucleophosmin B23 & rRNA processing & Nucleolus & $\mathrm{LAAD}^{161}, \mathrm{VEVD}^{122}$ & $(271,272)$ \\
\hline PMScl/EXOSC10 & mRNA degradation & Cytosol & $\mathrm{VEQD}^{252}$ & $(269)$ \\
\hline Poly(ADP)ribose polymerase 1 (PARP1) & Ribosylation & Nucleus & VDPD $^{537}$ & $(269,281)$ \\
\hline Postmeiotic segregation 1 (PMS1) & DNA mismatch repair & Nucleus & ISAD $^{496}$ & $(269)$ \\
\hline Postmeiotic segregation 2 (PMS2) & DNA mismatch repair & Nucleus & $\mathrm{VEKD}^{493}$ & $(269)$ \\
\hline Procaspase-3 & Apoptosis execution & Cytosol & IETD $^{175}$ & $(151)$ \\
\hline Procaspase-7 & Apoptosis execution & Cytosol & IQAD $^{198}$ & $(151,152)$ \\
\hline Procaspase- 8 & Apoptosis initiation & Cytosol & ND & $(160,273)$ \\
\hline Procaspase-10 & Apoptosis initiation & Cytosol & IEAD $^{372}$ & $(151)$ \\
\hline Procaspase-9 & Apoptosis initiation & Cytosol & PEPD $^{315}$ & $(158)$ \\
\hline Procaspase-2 & Apoptosis initiation & Cytosol, nucleus & ND & $(265)$ \\
\hline
\end{tabular}


Table I. Continued.

\begin{tabular}{|c|c|c|c|c|}
\hline Protein & Function & Localization & Cleavage sites & Refs. \\
\hline Pyruvate dehydrogenase complex E2 (PDC-E2) & Acetyl-CoA synthesis & Mitochondria & ND & $(282)$ \\
\hline $\begin{array}{l}\text { Rho-associated coiled coil-containing } \\
\text { protein kinase } 2 \text { (ROCK II) }\end{array}$ & $\begin{array}{l}\text { Plasma membrane } \\
\text { blebbing (zeiosis) }\end{array}$ & Cytosol & IGLD $^{1131}$ & $(188)$ \\
\hline RNA polymerase I (RNA Pol I) & Transcription & Nucleus & $\mathrm{ICPD}^{448}$ & $(269)$ \\
\hline RNA polymerase II (RNA Pol II) & Transcription & Nucleus & ITPD $^{370}$ & $(269)$ \\
\hline $\begin{array}{l}\text { Signal recognition particle } 72 \mathrm{kDa} \\
\text { (SRP-72) }\end{array}$ & Translation & Cytosol & VTPD $^{573}$ & $(269)$ \\
\hline $\begin{array}{l}\text { Subunit A of DNA fragmentation factor } \\
\text { (DFFA/DFF45) }\end{array}$ & $\begin{array}{l}\text { Chaperone and inhibitor } \\
\text { of DFFB (DFF40) } \\
\text { deoxyribonuclease }\end{array}$ & Nucleus, cytosol & DETD $^{117}$, VTGD $^{6}$ & $(175,279)$ \\
\hline Topoisomerase I (Topo-1) & Transcription & Nucleus & $\mathrm{IEAD}^{15}$ & $(269)$ \\
\hline$\alpha$-Tubulin & $\begin{array}{l}\text { Microtubule poly- } \\
\text { merization/aggregation }\end{array}$ & Cytosol & $\mathrm{VGVD}^{438}$ & $(185,268)$ \\
\hline $\begin{array}{l}\text { U1 small nuclear ribonucleoprotein } \\
70 \mathrm{kDa}(\mathrm{U} 1-70 \mathrm{kDa})\end{array}$ & RNA processing & Nucleus & LGND $^{409}$ & $(269)$ \\
\hline UBF/NOR-90 & Nucleolar transcription factor & Nucleolus & $\mathrm{VRPD}^{220}$ & $(269)$ \\
\hline Ubiquitin fusion degradation 2 (UFD2) & Ubiquitination & Nucleus & VDVD $^{123}$ & $(283)$ \\
\hline
\end{tabular}

${ }^{\mathrm{a} N D}$, not determined; ${ }^{\mathrm{b}} \mathrm{MOMP}$, mitochondrial outer membrane permeabilization.

Although native glycosylated GrB binds to CI-MPR (136), cells lacking this receptor are readily killed by glycosylated $\mathrm{GrB}$ (124). Therefore, a different model for GrB cell uptake has been propounded. It suggests that selective $\mathrm{GrB}$ receptors may not be required and that the positively charged free GrB (having the isoelectric point of approximately 9.5-10) adsorbs to the targets, having negatively charged surface structures, mostly via non-specific electrostatic interactions $(128,140)$. One difficulty with this model is that the high positive charge of GrB is probably neutralized in vivo by SG, rendering adsorption to the cell surface much less efficient. It is therefore to posit that GrB exchanges from SG to more negatively charged elements on the cell surface, such as phospholipid headgroups, sulphated lipids, gangliosides, or heparan sulphate proteoglycans, and is subsequently internalized by absorptive pinocytosis $(125,127)$.

Even though the experimental evidence for the involvement of both the receptor-mediated endocytosis and receptorindependent absorptive pinocytosis of GrB entry into cells is strongly convincing, it is probable that these $\mathrm{GrB}$ uptake mechanisms can co-exist in the same cell.

The role of perforin in granzyme $B$ delivery into the target cell cytoplasm. GrB itself does not possess a capacity to bind and disrupt lipid membranes (131). However, there is clear evidence that GrB internalization into a target cell depends on PFN (141). PFN is a pore-forming glycoprotein that can bind to phospholipid components of target cell membranes in the presence of $\mathrm{Ca}^{2+}$ ions and subsequently oligomerizes to form pores with a diameter of 5-20 nm (142-145). Contrary to progranzymes, which are activated by dipeptidyl peptidase I (DPPI), proteolytic processing of the perforin precursor occurs in the absence of DPPI activity (98). There are two well-founded hypotheses explaining the process of the PFNassisted GrB entry into the cytoplasm of target cells. First, the pore entry hypothesis states that GrB and other granzymes are primarily translocated from the cell exterior (e.g., IS) into the cytoplasm through repairable plasma membrane pores by diffusion (146). However, recent data indicate that GrB likely does not enter the cytoplasm through PFN pores at the plasma membrane since inhibiting the PFN-activated endocytosis increases the number of PFN pores persisting at the cell surface, but decreases the GrB uptake (132). Nevertheless, PFN oligomerization and transmembrane pore assembly is a prerequisite for the GrB-induced apoptosis (147). Second, the endosome permeabilization/endosomolysis entry hypothesis claims that GrB and other granzymes are delivered into the target cell cytoplasm after endocytosis and via a PFN-mediated disruptive escape from the endosomal compartment (120, $123,126)$. The precise mechanism of the perforin-assisted GrB cytosolic translocation from this compartment has not been elucidated yet.

\section{Death pathways activated by granzyme $B$ in cancer cells}

Once $\mathrm{GrB}$ is delivered into the cytosol it can proteolytically attack different protein substrates and initiate programmed cell death. To date, more than three hundreds intracellular and extracellular human proteins as potential GrB substrates have been identified $(56,58,148)$. The list of the proteins cleaved by GrB during apoptosis is indicated in Table I. However, only for a few of them the physiological relevance of their cleavage in the process of cell demise is established. 
Direct proteolytic activation of executioner procaspases. GrB has a similar preference as caspases for cleaving protein peptide bonds C-terminal to Asp residue $(114,115)$. GrB is capable of direct proteolytic processing and activation of the executioner procaspase-3 and -7 (43,149-156). On the other hand, there are contradictory reports on the direct GrB-mediated procaspase- 6 proteolytic activation $(43,157,158)$. Moreover, the apoptotic procaspases including procaspase- $8,-10,-9$, and -2 were reported to serve as substrates for the active $\operatorname{GrB}(43,151$, 158-162,265). However, it should be emphasized that GrB can proteolytically cleave these initiator procaspases but it cannot activate them. The initiator procaspases are activated exclusively by homodimerization in specific multiprotein activation platforms such as apoptosome, DISC and PIDDosome $(1,4,6,19,31)$.

Mitochondrial outer membrane permeabilization (MOMP). Some authors believe that GrB preferentially triggers apoptosis through an alteration of the outer mitochondrial membrane (OMM) rather than by the direct activation of the executioner caspases (163). GrB can disrupt OMM at least by two distinct mechanisms. First, GrB cleaves and activates the cytosolic $\mathrm{BH} 3$-only protein Bid, which C-terminal proteolytic fragment, $\mathrm{t}(\mathrm{c}) \mathrm{Bid}$, translocates to outer mitochondrial membrane and promotes its permeabilization (164-169). Through the t(c)Bidmediated MOMP several pro-apoptotic mitochondrial proteins are released into the cytoplasm and trigger caspase-dependent and -independent death pathways (see above). Second, the proteolytic disruption of the Mcl-1•Bim complex at OMM by GrB may constitute an alternative and/or parallel mechanism of the GrB-induced MOMP. Herein, GrB cleaves the Mcl-1 component of the complex relieving the OMM-permeabilizing activity of Bim $(40,41)$. Moreover, it was recently discovered that $\mathrm{GrB}$ translocates into the mitochondria of target cells and cleaves the HS-1-associated protein X-1 (Hax-1) (170). The resulting N-terminal Hax-1 fragment is responsible for mitochondrial depolarization.

Intracellular housekeeping protein substrates of granzyme B. $\mathrm{GrB}$ has an important role in dismantling the cytoskeleton by cleaving of several its protein components such as $\alpha$-tubulin (43), filamin (186), $\beta$-fodrin (187) and Rhoassociated coiled coil-containing protein kinase 2 (ROCK II) (188).

Besides that, GrB could disrupt the cohesiveness of the nuclear lamina by direct cleaving of lamin B (189). This opens an intriguing possibility that disruption of the nuclear lamina by $\mathrm{GrB}$ and other granzymes facilitates their nuclear entry through nuclear pore complexes (189). Once in the nucleus, GrB cleaves several nuclear protein substrates and thus triggers many critical intranuclear molecular processes (Table I).

Another class of GrB substrates represent transmembrane receptors for growth factors, such as Notch1 and fibroblast growth factor receptor-1 (FGFR-1) that transmit pro-survival and pro-proliferative signals from the extracellular environment (190), and members of the heat shock/stress response family (Hsp) including Hsp70, Hsp90, Bag1-L, Hsp70/Hsp-90organizing protein (Hop), and Hsc70/Hsp70-interacting protein (Hip) (191-193).
The high sequence homology and conserved primary cleavage specificity of human and mouse granzymes has led to widespread and interchangeable use of human and mouse enzymes in experimental conditions, usually without side-byside comparisons being made (194-196). Human and mouse GrB exhibit substantial difference in their ability to cleave Bid, as well as several other protein substrates, such as DFFA and procaspase- $8(43,195)$. Conclusions based on mixing human enzymes with mouse protein substrates and vice versa should be always interpreted with caution.

Intranuclear translocation and direct activation of DNA fragmentation factor. Once delivered into the cytoplasm of target cells, GrB is rapidly translocated to the nucleus (171-173). The detailed mechanism by which GrB translocates into and accumulates within the nucleus and nucleolus is still unclear. Both unglycosylated and the high-mannose glycan moiety bearing GrB molecules can be imported into the nucleus, but GrB molecules containing complex glycan moieties are exclude from the nuclear entry (171). The nuclear GrB import is independent of both ATP and GTP, but it seems to be dependent on certain cytosolic factors including importin (IMP)- $\alpha$ (171-174). GrB delivered into the cytoplasm is a target of the cytosolic proteinase inhibitor-9 (PI-9)/serpinB9 which forms with $\mathrm{GrB}$ a covalent inhibitory complex (see below). By competing with free GrB for binding to IMP- $\alpha$, the GrB $\bullet P I-9$ complex may prevent the nuclear import of active GrB (174).

Within the nucleus, GrB directly cleaves the subunit A of DNA fragmentation factor (DFF) (175), which is a heterodimer of the inhibitor/chaperone subunit A (DFFA) and the nuclease subunit B (DFFB), and is prebound to DNA (10). The DFFB subunit, escaped from the proteolytically fragmented DFFA subunit, becomes catalytically competent via homodimerization and/or oligomerization and cleaves both strands of the genomic DNA, producing mostly blunt-ended DNA fragments showing a typical oligonucleosomal ladder pattern upon electrophoresis $(10,176)$. The GrB-mediated DFF activation can be an alternative way leading to apoptotic DNA fragmentation in cancer cells which are unable to translocate the active caspase-3, a main DFF activator (176), into the nucleus (cf. 177 ) or carry a loss-of-function mutation of the CASP3 gene (178). Besides DFF, GrB can cleave several other nuclear proteins, see Table I.

Detachment of cells from extracellular matrix and anoikis. Both newly synthesized GrB zymogen and active GrB are constitutively and non-specifically released from CTLs (133). Once secreted, the active GrB can cleave extracellular matrix components including vitronectin, fibronectin and laminin $(179,180)$. This can induce the detachment-triggered cell death, i.e., anoikis (179-181). In general, modulation of cell adhesion by GrB may have important biological and pathobiological consequences. Due to extracellular matrix remodelling, GrB may contribute to migration of activated leukocytes through tissues. Moreover, the secreted GrB may either inhibit tumourigenesis via inducing anoikis of tumour cells, e.g., in early stages of tumour development, or it may facilitate tumourigenesis through promoting tumour cell spreading, migration and invasion (181-184). 


\section{Regulation of granzyme B activity}

It remains a puzzle how one CTL can kill multiple target cells over longer periods of time without self-destruction and why tumour cells or virus-infected cells became resistant to granule-mediated apoptosis. Several candidate regulators of GrB activity have been identified. First, the serpin proteinase inhibitor-9 (PI-9)/serpinB9 was identified and established as a powerful inhibitor of $\operatorname{GrB}(197,198)$. Second, some granzymes co-secreted with GrB, such as GrM and GrH, have a potential to influence the activity of $\mathrm{GrB}$ indirectly. They both can promote GrB activity through the direct cleavage and inactivation of protein inhibitors of $\mathrm{GrB}$, the former destroys PI-9 in a variety of target cells (199) whereas the latter attacks L4-100K protein, the adenoviral GrB inhibitor, in the virally infected cells (200). Moreover, certain cell surface-bound and/or secreted proteases, such as cathepsin B, might play a role in controlling the susceptibility of various tumour cells to the CTL-mediated killing via the proteolytic inactivation of PFN (cf. 201).

\section{Viral GrB inhibitors}

Cytokine response modifier A (CrmA). CrmA, a cowpox virus-derived $39 \mathrm{kDa}$ serpin protein, through the inhibition of caspase-1 plays an important role in regulating the response associated with the cowpox virus infection (202). Besides this anti-inflammatory activity, CrmA also suppresses the CTL-induced apoptosis of tumour cells via targeting and inhibiting both the GrB- and caspase-8-initiated death pathways (203-206). Due to the inhibition of GrB, a serine proteinase, and some caspases, which are cysteine proteinases, $\mathrm{CrmA}$ is classified as a 'cross-class' protein inhibitor of proteinases (207). Interestingly, CrmA and proteinase inhibitor-9 (PI-9)/ serpinB9, a member of the ovalbumin serpin family, show extensive structural homology (197), leading to suggestion that PI-9 might also function as a 'cross-class' protein inhibitor of proteinases (see below).

Adenoviral L4-100K protein. Another member of the viral family of GrB inhibitors is the adenovirus assembly protein L4-100K/Ad5-100K, which is involved in the life cycle of human adenovirus type 5 (Ad5), including virus assembly and activation of late viral protein synthesis $(208,209)$. This protein is a substrate for $\mathrm{GrB}$ and inhibits the protease through an unclear mechanism involving interactions of L4-100K with both the active site and an exosite in the GrB molecule (209). The inhibitory effect of L4-100K on GrB can be eliminated by $\mathrm{GrH}$ which can proteolytically inactivate this adenoviral protein (200).

\section{Non-viral granzyme B inhibitors}

Proteinase inhibitor-9 (serpinB9). Human proteinase inhibitor-9 (PI-9)/serpinB9 is a 42-kDa intracellular protein. It is a member of the serpin superfamily, an ovalbumin family serpin (i.e., a clade B serpin) $(210,211)$. Members of this family lack, by definition, a classical secretory signal peptide $(211,212)$. PI-9 is an efficient and highly specific physiological inhibitor of $\mathrm{GrB}\left(\mathrm{K}_{\mathrm{ass}}=1.7 \times 10^{6} \mathrm{M}^{-1} \cdot \mathrm{s}^{-1}\right)$ that protects CTLs themselves, as well as bystander cells from misdirected $\mathrm{GrB}$ $(198,213,214)$.
SERPINB9 gene organization and expression, and subcellular localization and function of proteinase inhibitor-9. SERPINB9 gene has been mapped to a gene cluster on the chromosome 6 at $\mathrm{p} 25$. Besides the SERPINB9 gene, the 6p25 region carries also SERPINB1 gene, encoding monocyte neutrophil elastase inhibitor (MNEI), and SERPINB6 gene, encoding cytoplasmic proteinase inhibitor-6 (PI-6) (215-219). SERPINB9 gene consists of seven exons and six introns $(219,220)$. The translation start site resides in exon 2 and the reactive centre (site) loop (RCL), a region of the PI-9 protein which is proteolytically attacked by $\mathrm{GrB}$, is encoded in exon 7 (220).

PI-9 is expressed abundantly in cells that produce high levels of GrB, i.e., in CD8 ${ }^{+} \mathrm{T}$ cells and NK cells $(198,214,221)$. The main physiological function of PI-9 is to protect these cells against the misdirected autogenous $\operatorname{GrB}(214,222)$. Moreover, PI-9 may also defend bystander cells or antigenpresenting cells likely to be exposed to GrB during an immune response $(214,222)$. Consistent with such a role is the expression of PI-9 in B cells (198), monocytes (223), mast cells (224), endothelial and mesothelial cells (225), smooth muscle cells (226) and dendritic cells $(214,227)$. Cells at immune-privileged sites, including the eye lens capsula, testes, ovary, placenta, and embryonic stem cells, also upregulate the PI-9 expression $(221,225,228)$.

The expression of PI-9 was also detected at highly variable levels in human cancer cells of carcinomas of the breast, cervix, nasopharynx, esophagus, stomach, colon, and lung, and melanomas $(93,229-233)$. The mechanisms responsible in vivo for the differential expression of PI-9 in these cancer cells are not known so far.

In a variety of cells, PI-9 protein is expressed in both the cytoplasm and the nucleus (234). This provides the PI-9expressing cells with efficient protection against the GrBmediated damage of target proteins inside of these compartments. The exact mechanisms of PI-9 nuclear import is unknown so far. On the other hand, sensitivity of PI-9 nuclear export to leptomycin B points to the involvement of Crm1 protein (234). This is consisted with the presence of a functionally conserved nuclear export signal in PI-9 protein (235).

PI-9 expression can be upregulated or induced in CTLs, a NK cell line YT-N10, endothelial cells, dendritic cells, human hepatocytes, hepatoma cell lines HepG2 and Huh-7, and gastric cancer cells by several cytokines and inflammatory mediators, such as interleukin (IL)-1ß, IL-18, TNF- $\alpha$, interferon- $\alpha$ and $-\gamma, 12-O$-tetradecanoylphorbol-13-acetate and lipopolysaccharide $(214,224,225,233,236-238)$. There is evidence that an activator protein-1 (AP-1) binding site and two nuclear factor (NF)- $\mathrm{BB}$ binding sites in the SERPINB9 gene promoter are involved in the IL-1ß-mediated PI-9 expression (236). Moreover, it has been demonstrated that estradiol-17ß and other estrogens can induce the expression of PI-9 in human hepatocytes and in the estrogen receptor (ER)- $\alpha$ positive hepatoma cell line HepG2-ER7 $(239,240)$. The estrogen-mediated induction of PI-9 expression in HepG2-ER7 cells and the breast cancer cells MCF-7 protect the tumour cells against the CTL- and NK cell-triggered apoptosis (241-243). The estrogen-triggered and ER- $\alpha$-mediated induction of SERPINB9 gene transcription occurs through a unique estrogen responsive unit (ERU) located approximately 
200 nucleotides downstream of the transcription start site. The ERU consists of an imperfect palindromic estrogen response element (ERE) being immediately adjacent to a direct repeat containing two consensus ERE half-sites separated by 13 nucleotides (DR13) (244).

In our studies, we detected only a weak or no increase of PI-9 mRNA expression in the IL-1ß-, IL-18-, and estradiol17ß-treated NSCLC cell lines (Rousalova et al, unpublished data). The highly variable PI-9 expression among NSCLC cell lines (93) together with the lack of PI-9 upregulation in NSCLC cells in response to ILs and estradiol-17ß (Rousalova et al, unpublished data) indicate that other factors are involved in the regulation of SERPINB9 gene expression in these cancer cells.

So far, there is evidence that the upregulated expression of PI-9 in cancer cells may contribute to their resistance against the immune mediated killing and thus it may promote tumour growth and progression $(232,243)$. High levels of PI-9 are associated with a poor therapeutic response and prognosis in lymphomas and melanomas $(232,245)$.

Proteinase inhibitor-9 structure and mechanism of inhibition. PI-9 is composed of 376 amino acids and its tertiary structure consists of nine $\alpha$-helices (denoted A-I) and three $\beta$-sheets (denoted A-C) $(210,220)$. The regions important for protease inhibition are located on $B$-sheet $A$ and the reactive centre loop (RCL). The RCL of PI-9 acts as a pseudosubstrate and contains a GrB cleavage site P1-P1' which equals to the residues $\mathrm{E}^{340}-\mathrm{C}^{341}$ (116). The RCL segment $\mathrm{VVAE}^{340}$-CCME represents an extended $\mathrm{P} 4-\mathrm{P} 4$ ' region important for interaction with $\mathrm{GrB}$, while the $\mathrm{P} 4$ ' residue $\mathrm{E}^{344}$ is required for efficient binding of PI-9 and GrB (116). PI-9 is a direct and irreversible GrB inhibitor which reacts with GrB with a stoichiometry of inhibition of 1:1 (198). Proteolytic cleavage of the PI-9 RCL by $\mathrm{GrB}$ causes a rapid conformational change in the serpin, resulting in the formation of a stable serpin-proteinase complex. Thus PI-9 represents a suicide substrate for GrB.

Recent findings indicate that PI-9 can inhibit not only the $\mathrm{GrB} /$ perforin-mediated death pathway but also the TNF- $\alpha-$, TRAIL- and FasL-triggered death pathways $(246,247)$. The inhibition of the death ligand-induced cell killing seems to reside in direct interaction of PI-9 with the intermediate active forms of caspase- 8 and -10 (247). This observation points to a possibility to classify PI-9 as a 'cross-class' proteinase inhibitor.

Other granzyme B inhibiting serpins. Another member of the intracellular serpin family, termed raPIT5a, was isolated from the rat pituitary gland $(248,249)$. This protein, expressed also in rat tissues other than the pituitary gland (249), showed a high amino acid sequence similarity to the sequence of PI-9 (248) and its incubation with human GrB resulted in the formation of an SDS-stable enzyme-inhibitor complex $(248,249)$.

Recently, Sipione et al discovered that a mouse serpin3n, which is expressed and secreted by Sertoli cells, is an inhibitor of mouse and human GrB (250). This serpin also forms an SDS-stable enzyme-inhibitor complex with GrB (250). In addition, the study also indicates that serpin $3 \mathrm{n}$ can be involved in the extracellular protection of Sertoli cells from harmful GrB-mediated immune reactions.

\section{Granzyme B and anticancer therapy}

Cancer disease is still primarily treated by surgery, chemotherapy, and radiotherapy in various combinations. Much hope is currently placed in so-called targeted therapies that can be directed rather selectively against cancer cells and that bypass the damage to normal cells of the body. Several targeting agents have been studied to some extend for clinical use, including monoclonal antibodies and antibody derivates, and more recently also non-immunoglobulin scaffold proteins (251). The utilization of these various affinity proteins in the tumour-targeted therapy can affect tumour growth and progression by altering the signal transduction pathways in cancer cells or by delivery of toxins, cytotoxic drugs or radionuclides to cancer cells.

Granzyme B-protein fusion constructs. The unique mechanism of action of GrB-based and tumour-targeted fusion agents may also enable novel effective combinations with other types of therapeutic agents or with other treatment modalities. Several reports have been published in which GrB was similarly used as an effector death inducing domain being fused to certain tumour targeting sequences (252).

The ErbB receptor family has been extensively studied as predictors in tumour targeting, primarily for therapy using monoclonal antagonistic antibodies and specific tyrosine kinase inhibitors (253). Two receptors in the ErbB family, epidermal growth factor receptor (EGFR) and epidermal growth factor receptor 2 (HER2), are overexpressed in various malignancies and are associated with poor prognosis of cancer patients. Therefore, they are interesting therapy targets in solid tumours. Novel chimeric fusion proteins, immunoGrBs, were generated by sequential fusion of an anti-HER2 single-chain antibody (e23sFv), the Pseudomonas exotoxin-A translocation domain, and the active $\mathrm{GrB}(254,255)$. Some of these ternary fusion proteins selectively recognized and destroyed HER2-overexpressing tumour cells both in vitro and in tumours xenotransplanted into nude mice $(254,255)$. They have a therapeutic potential especially in conditions when the caspase-dependent apoptosis of cancer cells is inhibited. Dalken and co-workers employed human $\mathrm{GrB}$ as an effector function in chimeric fusion proteins that contained the EGFR ligand TGF- $\alpha$ or an ErbB2-specific single-chain antibody fragment (scFv) for selective therapeutic targeting of tumour cells (256). Furthermore, a novel vascular-targeting fusion construct was developed for anti-angiogenic tumour therapy, where GrB was fused with a non-heparin-binding isoform of VEGF (257).

In addition, several authors coupled the active GrB with anti-tumour antibodies, e.g., the anti-melanoma antibody scFvMEL (anti-gp240) (258), the Lewis Y-binding antibody dsFv-B3 (259) or the antibody directed against CD64 (260).

Finally, another potential mechanism how to enhance susceptibility of tumour cells to immune-mediated killing is based on the protection of the caspase-dependent arm of the GrB-mediated apoptosis by neutralization of the inhibitor of apoptosis proteins via the second mitochondria-derived activator of caspase (Smac). This goal can be achieved by overexpression of a recombinant pro-Smac fusion protein, containing a GrB-specific cleavage/activation site, in target tumour cells and subsequent exposure to LAK cells (261). 
SAGA fusion construct. Caldas and colleagues developed a novel hybrid vector called Survivin and GrB-induced apoptosis (SAGA). This hybrid cDNA construct contained a fusion of the minimum human survivin gene (BIRC5) promoter with the coding sequence of the active form of human $\mathrm{GrB}$. The growth inhibitory effect of SAGA in vitro was tested on multiple cancer cell lines, including hepatocellular, colorectal, lung, breast, cervical and ovarian carcinomas, leukemias, central nervous system tumours, soft tissue sarcomas, and osteosarcomas. SAGA alone or in a combination with chemotherapeutic agents, such as vincristine or paclitaxel, efficiently inhibited cell growth in all cancer cell lines tested. Furthermore, the tumour specificity of SAGA was demonstrated (262). Based on these observations, SAGA could represent in future a novel alternative treatment option for many human malignancies which overexpress the survivin gene.

\section{Conclusion and the future directions of research}

Current evidence indicates that $\mathrm{GrB}$ is the main effector of CTLs and NK cells in their killing attack on cancer cells. There are multiple protein targets of GrB within cancer cells and the proteinase, after crossing the membrane of endosomes, is distributed into several subcellular compartments including the cytoplasm, the nucleus and mitochondria. Even though our understanding of GrB involvement in cancer cell apoptosis has been substantially advanced during the last years, the list of cell death-related GrB protein substrates is still expanding and the molecular mechanisms of GrB entry into the cytoplasm, nucleus and mitochondria remain to be clarified. The efficiency of GrB-induced apoptosis of cancer cells mainly depends on the amount of GrB which is delivered into their cytoplasm and escapes from inactivation by PI-9. Although the presence of endogenous $\mathrm{GrB}$ is detected in cancer cells of some tumours, it is still unknown whether the proteinase is their own active product or the gained one from CTLs and/or NK cells. If some cancer cells were expressing and releasing the secretory forms of active/activatable GrB, the proteinase might be involved either in promoting or suppressing of both tumour growth and progression (see above). The studies mentioned above demonstrate that delivery of an expressable cDNA fusion construct encoding an active form of GrB into tumour cells might be a promising therapeutic tool for cancer treatment.

Several important questions concerning the involvement of GrB and its specific inactivator PI-9 in apoptosis of cancer cells warrant investigation. First, there is a possibility that certain cancer cell-specific signalling pathways may lead to upregulation of $\mathrm{GrB}$ and perforin expression in tumour infiltrating CTLs and NK cells and to targeted delivery of these molecules to cancer cells (cf. 263). Second, studies should address the question whether proGrB is released into the IS during vectorial degranulation of cancer cell-conjugated CTLs and NK cells and whether the proenzyme is subsequently internalized into the cancer cells and undergoes activation there. Third, further studies should clarify if the placement of a hypoxia response element sequence into the survivin promoter fused with cDNA sequence encoding active GrB can increase the expression activity and therapeutic effectiveness of such SAGA construct (262) under hypoxic conditions, which are typically present in solid tumours. Fourth, the positive regulation of transcriptional expression of SERPINB9 gene by estrogens (241-243) deserves systematic investigation in the estrogen-responsive tumours bearing ER $\alpha$, especially in breast, uterine and ovarian carcinomas. The rationale for these studies is to elucidate whether the overexpression of PI-9 may predict more aggressive and therapeutically resistant tumours (cf. 232). Finally, because of profound variability of PI-9 expression in tumours of the same histopathological type, ranging from very high to barely detectable PI-9 mRNA levels (cf. 93,229), it is important to determine whether the SERPINB9 gene is a target for epigenetic reprogramming in cancer cells (264).

\section{Acknowledgements}

This work was supported by research projects MZO 00064211 and NS/9715-4 from the Ministry of Health, Czech Republic.

\section{References}

1. Peter ME and Krammer PH: The CD95(APO-1/Fas) DISC and beyond. Cell Death Differ 10: 26-35, 2003.

2. Falschlehner C, Emmerich $\mathrm{CH}$, Gerlach B and Walczak H: TRAIL signalling: decisions between life and death. Int J Biochem Cell Biol 39: 1462-1475, 2007.

3. Sandu C, Gavathiotis E, Huang T, Wegorzewska I and Werner MH: A mechanism for death receptor discrimination by death adaptors. J Biol Chem 280: 31974-31980, 2005.

4. Pennarun B, Meijer A, De Vries EG, Kleibeuker JH, Kruyt F and De Jong S: Playing the DISC: turning on TRAIL death receptor-mediated apoptosis in cancer. Biochim Biophys Acta 1805: 123-140, 2010.

5. Chang DW, Xing Z, Capacio VL, Peter ME and Yang X: Interdimer processing mechanism of procaspase- 8 activation. EMBO J 22: 4132-4142, 2003

6. Pop C and Salvesen GS: Human caspases: activation, specificity, and regulation. J Biol Chem 284: 21777-21781, 2009.

7. Milhas D, Cuvillier O, Therville N, et al: Caspase-10 triggers Bid cleavage and caspase cascade activation in FasL-induced apoptosis. J Biol Chem 280: 19836-19842, 2005.

8. Fischer U, Stroh C and Schulze-Osthoff K: Unique and overlapping substrate specificities of caspase- 8 and caspase- 10 . Oncogene 25: 152-159, 2006.

9. Billen LP, Shamas-Din A and Andrews DW: Bid: a Bax-like BH3 protein. Oncogene 27 (Suppl 1): S93-S104, 2008.

10. Widlak P and Garrard WT: Discovery, regulation, and action of the major apoptotic nucleases DFF40/CAD and endonuclease G. J Cell Biochem 94: 1078-1087, 2005.

11. Kroemer G, Galluzzi L and Brenner C: Mitochondrial membrane permeabilization in cell death. Physiol Rev 87: 99-163, 2007.

12. Martinez-Ruiz G, Maldonado V, Ceballos-Cancino G, Grajeda JP and Melendez-Zajgla J: Role of Smac/DIABLO in cancer progression. J Exp Clin Cancer Res 27: 48, 2008.

13. Jiang X and Wang X: Cytochrome c-mediated apoptosis. Annu Rev Biochem 73: 87-106, 2004.

14. Kim HE, Du F, Fang M and Wang X: Formation of apoptosome is initiated by cytochrome c-induced dATP hydrolysis and subsequent nucleotide exchange on Apaf-1. Proc Natl Acad Sci USA 102: 17545-17550, 2005.

15. Yu X, Acehan D, Menetret JF, et al: A structure of the human apoptosome at $12.8 \AA$ resolution provides insights into this cell death platform. Structure 13: 1725-1735, 2005.

16. Stennicke HR, Deveraux QL, Humke EW, Reed JC, Dixit VM and Salvesen GS: Caspase-9 can be activated without proteolytic processing. J Biol Chem 274: 8359-8362, 1999.

17. Bratton SB, Walker G, Srinivasula SM, Sun XM, Butterworth M, Alnemri ES and Cohen GM: Recruitment, activation and retention of caspases- 9 and -3 by Apaf-1 apoptosome and associated XIAP complexes. EMBO J 20: 998-1009, 2001.

18. Pop C, Timmer J, Sperandio S and Salvesen GS: The apoptosome activates caspase-9 by dimerization. Mol Cell 22: 269-275, 2006. 
19. Malladi S, Challa-Malladi M, Fearnhead HO and Bratton SB: The Apaf-1•procaspase-9 apoptosome complex functions as a proteolytic-based molecular timer. EMBO J 28: 1916-1925, 2009

20. Slee EA, Adrain C and Martin SJ: Executioner caspase-3, -6, and -7 perform distinct, non-redundant roles during the demolition phase of apoptosis. J Biol Chem 276: 7320-7326, 2001.

21. Guerrero AD, Chen M and Wang J: Delineation of the caspase-9 signaling cascade. Apoptosis 13: 177-186, 2008.

22. Inoue S, Browne G, Melino G and Cohen GM: Ordering of caspases in cells undergoing apoptosis by the intrinsic pathway. Cell Death Differ 16: 1053-1061, 2009.

23. Vande WL, Lamkanfi $\mathrm{M}$ and Vandenabeele P: The mitochondrial serine protease HtrA2/Omi: an overview. Cell Death Differ 15: 453-460, 2008.

24. Modjtahedi N, Giordanetto F, Madeo F and Kroemer G: Apoptosis-inducing factor: vital and lethal. Trends Cell Biol 16: 264-272, 2006

25. Tinel A and Tschopp J: The PIDDosome, a protein complex implicated in activation of caspase- 2 in response to genotoxic stress. Science 304: 843-846, 2004.

26. Park HH, Logette E, Raunser S, Cuenin S, Walz T, Tschopp J and $\mathrm{Wu} \mathrm{H}$ : Death domain assembly mechanism revealed by crystal structure of the oligomeric PIDDosome core complex. Cell 128: 533-546, 2007.

27. Shi M, Vivian CJ, Lee KJ, et al: DNA-PKcs-PIDDosome: a nuclear caspase-2-activating complex with role in G2/M checkpoint maintenance. Cell 136: 508-520, 2009.

28. Bouchier-Hayes L, Oberst A, McStay GP, et al: Characterization of cytoplasmic caspase-2 activation by induced proximity. Mol Cell 35: 830-840, 2009

29. Tinel A, Janssens S, Lippens S, et al: Autoproteolysis of PIDD marks the bifurcation between pro-death caspase- 2 and prosurvival NF-kappaB pathway. EMBO J 26: 197-208, 2007.

30. Kitevska T, Spencer DM and Hawkins C: Caspase-2: controversial killer or checkpoint controller? Apoptosis 14: 829-848, 2009

31. Krumschnabel G, Sohm B, Bock F, Manzl C and Villunger A: The enigma of caspase-2: the laymen's view. Cell Death Differ 16: 195-207, 2009.

32. Werneburg NW, Guicciardi ME, Bronk SF, Kaufmann SH and Gores GJ: Tumor necrosis factor-related apoptosis-inducing ligand activates a lysosomal pathway of apoptosis that is regulated by Bcl-2 proteins. J Biol Chem 282: 28960-28970, 2007.

33. Boya P and Kroemer G: Lysosomal membrane permeabilization in cell death. Oncogene 27: 6434-6451, 2008.

34. Oberle C, Huai J, Reinheckel T, et al: Lysosomal membrane permeabilization and cathepsin release is a Bax/Bak-dependent amplifying event of apoptosis in fibroblasts and monocytes. Cell Death Differ 17: 1167-1178, 2010

35. Turk B and Stoka V: Protease signalling in cell death: caspases versus cysteine cathepsins. FEBS Lett 581: 2761-2767, 2007

36. Stoka V, Turk V and Turk B: Lysosomal cysteine cathepsins: signaling pathways in apoptosis. Biol Chem 388: 555-560, 2007.

37. Turk B and Turk V: Lysosomes as 'suicide bags' in cell death: myth or reality? J Biol Chem 284: 21783-21787, 2009.

38. Fischer U, Jänicke RU and Schulze-Osthoff K: Many cuts to ruin: a comprehensive update of caspase substrates. Cell Death Differ 10: 76-100, 2003.

39. Timmer JC and Salvesen GS: Caspase substrates. Cell Death Differ 14: 66-72, 2007.

40. Han J, Goldstein LA, Gastman BR, Froelich CJ, Yin XM and Rabinowich H: Degradation of Mcl-1 by granzyme B: implications for Bim-mediated mitochondrial apoptotic events. J Biol Chem 279: 22020-22029, 2004

41. Han J, Goldstein LA, Gastman BR, Rabinovitz A and Rabinowich $\mathrm{H}$ : Disruption of $\mathrm{Mcl}-1 \cdot \mathrm{Bim}$ complex in granzyme B-mediated mitochondrial apoptosis. J Biol Chem 280: 16383-16392, 2005.

42. Herrant M, Jacquel A, Marchetti S, Belhacene N, Colosetti P, Luciano $\mathrm{F}$ and Auberger P: Cleavage of Mcl-1 by caspases impaired its ability to counteract Bim-induced apoptosis. Oncogene 23: 7863-7873, 2004.

43. Adrain C, Murphy BM and Martin SJ: Molecular ordering of the caspase activation cascade initiated by the cytotoxic $\mathrm{T}$ lymphocyte/natural killer (CTL/NK) protease granzyme B. J Biol Chem 280: 4663-4673, 2005

44. Yin XM: Bid, a BH3-only multi-functional molecule, is at the cross road of life and death. Gene 369: 7-19, 2006.

45. Russell JH and Ley TJ: Lymphocyte-mediated cytotoxicity. Annu Rev Immunol 20: 323-370, 2002.
46. Clayberger C: Cytolytic molecules in rejection. Curr Opin Organ Transplant 14: 30-33, 2009.

47. Froelich CJ, Pardo J and Simon MM: Granule-associated serine proteases: granzymes might not just be killer proteases. Trends Immunol 30: 117-123, 2009.

48. Choy JC: Granzymes and perforin in solid organ transplant rejection. Cell Death Differ 17: 567-576, 2010.

49. Cullen SP, Brunet M and Martin SJ: Granzymes in cancer and immunity. Cell Death Differ 17: 616-623, 2010.

50. Topham NJ and Hewitt EW: Natural killer cell cytotoxicity: how do they pull the trigger? Immunology 128: 7-15, 2009.

51. Jenkins MR and Griffiths GM: The synapse and cytolytic machinery of cytotoxic T cells. Curr Opin Immunol 22: 308-313, 2010.

52. Mahrus S and Craik CS: Selective chemical functional probes of granzymes A and B reveal granzyme B is a major effector of natural killer cell-mediated lysis of target cells. Chem Biol 12: 567-577, 2005.

53. Cullen SP and Martin SJ: Mechanisms of granule-dependent killing. Cell Death Differ 15: 251-262, 2008.

54. Buzza MS and Bird PI: Extracellular granzymes: current perspectives. Biol Chem 387: 827-837, 2006.

55. Romero V and Andrade F: Non-apoptotic functions of granzymes. Tissue Antigens 71: 409-416, 2008

56. Boivin WA, Cooper DM, Hiebert PR and Granville DJ: Intracellular versus extracellular granzyme B in immunity and disease: challenging the dogma. Lab Invest 89: 1195-1220, 2009.

57. Afonina IS, Cullen SP and Martin SJ: Cytotoxic and non-cytotoxic roles of the CTL/NK protease granzyme B. Immunol Rev 235: 105-116, 2010.

58. Darrah E and Rosen A: Granzyme B cleavage of autoantigens in autoimmunity. Cell Death Differ 17: 624-632, 2010.

59. Klein JL, Shows TB, Dupont B and Trapani JA: Genomic organization and chromosomal assignment for a serine protease gene (CSPB) expressed by human cytotoxic lymphocytes. Genomics 5: 110-117, 1989 .

60. Heusel JW, Hanson RD, Silverman GA and Ley TJ: Structure and expression of a cluster of human hematopoietic serine protease genes found on chromosome 14q11.2. J Biol Chem 266: 6152-6158, 1991

61. Haddad P, Clement MV, Bernard O, Larsen CJ, Degos L, Sasportes M and Mathieu-Mahul D: Structural organization of the hCTLA-1 gene encoding human granzyme B. Gene 87: 265-271, 1990 .

62. Trapani JA: Granzymes: a family of lymphocyte granule serine proteases. Genome Biol 2: REVIEWS3014, 2001.

63. Haddad P, Wargnier A, Bourge JF, Sasportes M and Paul P: A promoter element of the human serine esterase granzyme B gene controls specific transcription in activated T cells. Eur J Immunol 23: 625-629, 1993.

64. Wargnier A, Lafaurie C, Legros-Maida S, Bourge JF, Sigaux F, Sasportes M and Paul P: Down-regulation of human granzyme B expression by glucocorticoids. Dexamethasone inhibits binding to the Ikaros and AP-1 regulatory elements of the granzyme B promoter. J Biol Chem 273: 35326-35331, 1998.

65. Huang C, Bi E, Hu Y, et al: A novel NF-kappaB binding site controls human granzyme B gene transcription. J Immunol 176: 4173-4181, 2006.

66. Jahrsdorfer B, Vollmer A, Blackwell SE, et al: Granzyme B produced by human plasmacytoid dendritic cells suppresses T-cell expansion. Blood 115: 1156-1165, 2010.

67. McIlroy D, Cartron PF, Tuffery P, et al: A triple-mutated allele of granzyme B incapable of inducing apoptosis. Proc Natl Acad Sci USA 100: 2562-2567, 2003.

68. Sun J, Bird CH, Thia KY, Matthews AY, Trapani JA and Bird PI: Granzyme B encoded by the commonly occurring human RAH allele retains pro-apoptotic activity. J Biol Chem 279: 16907-16911, 2004.

69. Garcia-Sanz JA, Velotti F, MacDonald HR, Masson D, Tschopp J and Nabholz M: Appearance of granule-associated molecules during activation of cytolytic T-lymphocyte precursors by defined stimuli. Immunology 64: 129-134, 1988.

70. Bleackley RC: A molecular view of cytotoxic T lymphocyte induced killing. Biochem Cell Biol 83: 747-751, 2005.

71. Berthou C, Michel L, Soulie A, et al: Acquisition of granzyme B and Fas ligand proteins by human keratinocytes contributes to epidermal cell defense. J Immunol 159: 5293-5300, 1997.

72. Namekawa T, Wagner UG, Goronzy JJ and Weyand CM: Functional subsets of CD4 T cells in rheumatoid synovitis. Arthritis Rheum 41: 2108-2116, 1998. 
73. Tordjmann T, Soulie A, Guettier C, Schmidt M, Berthou C, Beaugrand M and Sasportes M: Perforin and granzyme B lytic protein expression during chronic viral and autoimmune hepatitis. Liver 18: 391-397, 1998.

74. Hirst CE, Buzza MS, Sutton VR, Trapani JA, Loveland KL and Bird PI: Perforin-independent expression of granzyme B and proteinase inhibitor 9 in human testis and placenta suggests a role for granzyme B-mediated proteolysis in reproduction. Mol Hum Reprod 7: 1133-1142, 2001.

75. Ronday HK, van der Laan WH, Tak PP, et al: Human granzyme B mediates cartilage proteoglycan degradation and is expressed at the invasive front of the synovium in rheumatoid arthritis. Rheumatology (Oxford) 40: 55-61, 2001.

76. Rissoan MC, Duhen T, Bridon JM, et al: Subtractive hybridization reveals the expression of immunoglobulin-like transcript 7 , Eph-B1, granzyme B, and 3 novel transcripts in human plasmacytoid dendritic cells. Blood 100: 3295-3303, 2002.

77. Amsterdam A, Sasson R, Keren-Tal I, et al: Alternative pathways of ovarian apoptosis: death for life. Biochem Pharmacol 66 1355-1362, 2003.

78. Horiuchi K, Saito S, Sasaki R, Tomatsu T and Toyama Y: Expression of granzyme B in human articular chondrocytes. J Rheumatol 30: 1799-1810, 2003.

79. Sasson R, Dantes A, Tajima K and Amsterdam A: Novel genes modulated by FSH in normal and immortalized FSH-responsive cells: new insights into the mechanism of FSH action. FASEB J 17: 1256-1266, 2003.

80. Wagner C, Iking-Konert C, Denefleh B, Stegmaier S, Hug F and Hansch GM: Granzyme B and perforin: constitutive expression in human polymorphonuclear neutrophils. Blood 103: 1099-1104, 2004.

81. Wagner C, Stegmaier S and Hansch GM: Expression of granzyme B in peripheral blood polymorphonuclear neutrophils (PMN), myeloid cell lines and in PMN derived from haemotopoietic stem cells in vitro. Mol Immunol 45: 1761-1766, 2008.

82. Strik MC, De Koning PJ, Kleijmeer MJ, et al: Human mast cells produce and release the cytotoxic lymphocyte associated protease granzyme B upon activation. Mol Immunol 44: 3462-3472, 2007.

83. Hernandez-Pigeon H, Jean C, Charruyer A, et al: Human keratinocytes acquire cellular cytotoxicity under UV-B irradiation. Implication of granzyme B and perforin. J Biol Chem 281: 13525-13532, 2006

84. Tschopp CM, Spiegl N, Didichenko S, et al: Granzyme B, a novel mediator of allergic inflammation: its induction and release in blood basophils and human asthma. Blood 108: 2290-2299, 2006.

85. Hernandez-Pigeon H, Jean C, Charruyer A, et al: UVA induces granzyme B in human keratinocytes through MIF: implication in extracellular matrix remodeling. J Biol Chem 282: 8157-8164, 2007

86. Kim WJ, Kim H, Suk K and Lee WH: Macrophages express granzyme B in the lesion areas of atherosclerosis and rheumatoid arthritis. Immunol Lett 111: 57-65, 2007.

87. Vernooy JH, Moller GM, van Suylen RJ, et al: Increased granzyme A expression in type II pneumocytes of patients with severe chronic obstructive pulmonary disease. Am J Respir Crit Care Med 175: 464-472, 2007

88. Kontani K, Sawai S, Hanaoka J, Tezuka N, Inoue S and Fujino S: Involvement of granzyme B and perforin in suppressing nodal metastasis of cancer cells in breast and lung cancers. Eur J Surg Oncol 27: 180-186, 2001

89. Hu SX, Wang S, Wang JP, Mills GB, Zhou Y and Xu HJ: Expression of endogenous granzyme B in a subset of human primary breast carcinomas. Br J Cancer 89: 135-139, 2003

90. D'Eliseo D, Pisu P, Romano C, et al: Granzyme B is expressed in urothelial carcinoma and promotes cancer cell invasion. Int J Cancer 127: 1283-1294, 2010.

91. Ko YH, Park S, Jin H, Woo H, Lee H, Park C and Kim K: Granzyme B leakage-induced apoptosis is a crucial mechanism of cell death in nasal-type NK/T-cell lymphoma. Lab Invest 87: 241-250, 2007

92. Costa NL, Alencar RC, Valadares MC, Silva TA, Mendonca EF and Batista AC: The clinicopathological significance of the expression of Granzyme B in oral squamous cell carcinoma. Oral Oncol 46: 185-189, 2010.

93. Rousalova I, Krepela E, Prochazka J, Cermak J and Benkova K: Expression of proteinase inhibitor-9/serpinB9 in non-small cell lung carcinoma cells and tissues. Int J Oncol 36: 275-283, 2010 .
94. Schmid J and Weissmann C: Induction of mRNA for a serine protease and a beta-thromboglobulin-like protein in mitogenstimulated human leukocytes. J Immunol 139: 250-256, 1987.

95. Krahenbuhl O, Rey C, Jenne D, Lanzavecchia A, Groscurth P, Carrel S and Tschopp J: Characterization of granzymes A and B isolated from granules of cloned human cytotoxic T lymphocytes. J Immunol 141: 3471-3477, 1988.

96. Trapani JA, Klein JL, White PC and Dupont B: Molecular cloning of an inducible serine esterase gene from human cytotoxic lymphocytes. Proc Natl Acad Sci USA 85: 6924-6928, 1988.

97. Poe M, Blake JT, Boulton DA, Gammon M, Sigal NH, Wu JK and Zweerink HJ: Human cytotoxic lymphocyte granzyme B. Its purification from granules and the characterization of substrate and inhibitor specificity. J Biol Chem 266: 98-103, 1991.

98. Meade JL, Wilson EB, Holmes TD, et al: Proteolytic activation of the cytotoxic phenotype during human NK cell development. J Immunol 183: 803-813, 2009.

99. Griffiths GM and Isaaz S: Granzymes A and B are targeted to the lytic granules of lymphocytes by the mannose-6-phosphate receptor. J Cell Biol 120: 885-896, 1993.

100. McGuire MJ, Lipsky PE and Thiele DL: Generation of active myeloid and lymphoid granule serine proteases requires processing by the granule thiol protease dipeptidyl peptidase I. J Biol Chem 268: 2458-2467, 1993.

101.Smyth MJ, McGuire MJ and Thia KY: Expression of recombinant human granzyme B. A processing and activation role for dipeptidyl peptidase I. J Immunol 154: 6299-6305, 1995.

102. Meade JL, De Wynter EA, Brett P, Sharif SM, Woods CG, Markham AF and Cook GP: A family with Papillon-Lefevre syndrome reveals a requirement for cathepsin $\mathrm{C}$ in granzyme $\mathrm{B}$ activation and NK cell cytolytic activity. Blood 107: 3665-3668, 2006.

103. Sutton VR, Waterhouse NJ, Browne KA, et al: Residual active granzyme B in cathepsin C-null lymphocytes is sufficient for perforin-dependent target cell apoptosis. J Cell Biol 176: 425-433, 2007

104. Methot N, Guay D, Rubin J, et al: In vivo inhibition of serine protease processing requires a high fractional inhibition of cathepsin C. Mol Pharmacol 73: 1857-1865, 2008.

105. D'Angelo ME, Bird PI, Peters C, Reinheckel T, Trapani JA and Sutton VR: Cathepsin $\mathrm{H}$ is an additional convertase of progranzyme B. J Biol Chem 285: 20514-20519, 2010.

106. Galvin JP, Spaeny-Dekking LH, Wang B, Seth P, Hack CE and Froelich CJ: Apoptosis induced by granzyme B-glycosaminoglycan complexes: implications for granule-mediated apoptosis in vivo. J Immunol 162: 5345-5350, 1999.

107. Metkar SS, Wang B, Aguilar-Santelises M, et al: Cytotoxic cell granule-mediated apoptosis: perforin delivers granzyme Bserglycin complexes into target cells without plasma membrane pore formation. Immunity 16: 417-428, 2002.

108. Raja SM, Wang B, Dantuluri M, et al: Cytotoxic cell granulemediated apoptosis. Characterization of the macromolecular complex of granzyme B with serglycin. J Biol Chem 277: 49523-49530, 2002.

109. Grujic M, Braga T, Lukinius A, Eloranta ML, Knight SD, Pejler G and Abrink M: Serglycin-deficient cytotoxic T lymphocytes display defective secretory granule maturation and granzyme B storage. J Biol Chem 280: 33411-33418, 2005 .

110. Sattar R, Ali SA and Abbasi A: Bioinformatics of granzymes: sequence comparison and structural studies on granzyme family by homology modeling. Biochem Biophys Res Commun 308: 726-735, 2003

111. Isaaz S, Baetz K, Olsen K, Podack E and Griffiths GM: Serial killing by cytotoxic $\mathrm{T}$ lymphocytes: $\mathrm{T}$ cell receptor triggers degranulation, re-filling of the lytic granules and secretion of lytic proteins via a non-granule pathway. Eur J Immunol 25: 1071-1079, 1995.

112. Estebanez-Perpina E, Fuentes-Prior P, Belorgey D, et al: Crystal structure of the caspase activator human granzyme B, a proteinase highly specific for an Asp-P1 residue. Biol Chem 381: 1203-1214, 2000.

113. Rotonda J, Garcia-Calvo M, Bull HG, et al: The threedimensional structure of human granzyme B compared to caspase-3, key mediators of cell death with cleavage specificity for aspartic acid in P1. Chem Biol 8: 357-368, 2001. 
114. Thornberry NA, Rano TA, Peterson EP, et al: A combinatorial approach defines specificities of members of the caspase family and granzyme B. Functional relationships established for key mediators of apoptosis. J Biol Chem 272: 17907-17911, 1997.

115. Harris JL, Peterson EP, Hudig D, Thornberry NA and Craik CS: Definition and redesign of the extended substrate specificity of granzyme B. J Biol Chem 273: 27364-27373, 1998.

116. Sun J, Whisstock JC, Harriott P, et al: Importance of the P4' residue in human granzyme $\mathrm{B}$ inhibitors and substrates revealed by scanning mutagenesis of the proteinase inhibitor 9 reactive center loop. J Biol Chem 276: 15177-15184, 2001.

117. Pores-Fernando AT and Zweifach A: Calcium influx and signaling in cytotoxic T-lymphocyte lytic granule exocytosis. Immunol Rev 231: 160-173, 2009.

118. Huse M, Quann EJ and Davis MM: Shouts, whispers and the kiss of death: directional secretion in $\mathrm{T}$ cells. Nat Immunol 9: $1105-1111,2008$

119. Liu CC, Walsh CM and Young JD: Perforin: structure and function. Immunol Today 16: 194-201, 1995

120. Froelich CJ, Orth K, Turbov J, et al: New paradigm for lymphocyte granule-mediated cytotoxicity. Target cells bind and internalize granzyme $\mathrm{B}$, but an endosomolytic agent is necessary for cytosolic delivery and subsequent apoptosis. J Biol Chem 271: 29073-29079, 1996.

121. Shi L, Mai S, Israels S, Browne K, Trapani JA and Greenberg AH: Granzyme B (GraB) autonomously crosses the cell membrane and perforin initiates apoptosis and GraB nuclear localization. J Exp Med 185: 855-866, 1997.

122.Pinkoski MJ, Hobman M, Heibein JA, et al: Entry and trafficking of granzyme B in target cells during granzyme Bperforin-mediated apoptosis. Blood 92: 1044-1054, 1998.

123. Browne KA, Blink E, Sutton VR, Froelich CJ, Jans DA and Trapani JA: Cytosolic delivery of granzyme B by bacteria toxins: evidence that endosomal disruption, in addition to transmembrane pore formation, is an important function of perforin. Mol Cell Biol 19: 8604-8615, 1999

124. Trapani JA, Sutton VR, Thia KY, et al: A clathrin/dynaminand mannose-6-phosphate receptor-independent pathway for granzyme B-induced cell death. J Cell Biol 160: 223-233, 2003.

125. Bird CH, Sun J, Ung K, Karambalis D, Whisstock JC, Trapani JA and Bird PI: Cationic sites on granzyme B contribute to cytotoxicity by promoting its uptake into target cells. Mol Cell Biol 25: 7854-7867, 2005.

126. Keefe D, Shi L, Feske S, Massol R, Navarro F, Kirchhausen T and Lieberman J: Perforin triggers a plasma membrane-repair response that facilitates CTL induction of apoptosis. Immunity 23: 249-262, 2005

127. Raja SM, Metkar SS, Honing S, et al: A novel mechanism for protein delivery: granzyme B undergoes electrostatic exchange from serglycin to target cells. J Biol Chem 280: 20752-20761, 2005 .

128. Shi L, Keefe D, Durand E, Feng H, Zhang D and Lieberman J: Granzyme B binds to target cells mostly by charge and must be added at the same time as perforin to trigger apoptosis. J Immunol 174: 5456-5461, 2005

129. Veugelers K, Motyka B, Goping IS, Shostak I, Sawchuk T and Bleackley RC: Granule-mediated killing by granzyme B and perforin requires a mannose 6-phosphate receptor and is augmented by cell surface heparan sulfate. Mol Biol Cell 17: 623-633, 2006.

130.Pipkin ME and Lieberman J: Delivering the kiss of death: progress on understanding how perforin works. Curr Opin Immunol 19: 301-308, 2007.

131. Besenicar MP, Metkar S, Wang B, Froelich CJ and Anderluh G: Granzyme B translocates across the lipid membrane only in the presence of lytic agents. Biochem Biophys Res Commun 371: 391-394, 2008.

132. Thiery J, Keefe D, Saffarian S, et al: Perforin activates clathrinand dynamin-dependent endocytosis, which is required for plasma membrane repair and delivery of granzyme B for granzyme-mediated apoptosis. Blood 115: 1582-1593, 2010.

133. Prakash MD, Bird CH and Bird PI: Active and zymogen forms of granzyme B are constitutively released from cytotoxic lymphocytes in the absence of target cell engagement. Immunol Cell Biol 87: 249-254, 2009.

134. Skold S, Zeberg L, Gullberg U and Olofsson T: Functional dissociation between proforms and mature forms of proteinase 3 , azurocidin, and granzyme $\mathrm{B}$ in regulation of granulopoiesis. Exp Hematol 30: 689-696, 2002.
135.Li P, Zheng G, Yang Y, et al: Granzyme B is recovered by natural killer cells via clathrin-dependent endocytosis. Cell Mol Life Sci 67: 3197-3208, 2010.

136. Motyka B, Korbutt G, Pinkoski MJ, et al: Mannose 6-phosphate/ insulin-like growth factor II receptor is a death receptor for granzyme B during cytotoxic $\mathrm{T}$ cell-induced apoptosis. Cell 103: 491-500, 2000.

137. Veugelers K, Motyka B, Frantz C, Shostak I, Sawchuk T and Bleackley RC: The granzyme B-serglycin complex from cytotoxic granules requires dynamin for endocytosis. Blood 103: 3845-3853, 2004.

138. Toyama-Sorimachi N, Sorimachi H, Tobita Y, Kitamura F, Yagita H, Suzuki K and Miyasaka M: A novel ligand for CD44 is serglycin, a hematopoietic cell lineage-specific proteoglycan. Possible involvement in lymphoid cell adherence and activation. J Biol Chem 270: 7437-7444, 1995.

139. Gross C, Koelch W, De Maio A, Arispe N and Multhoff G: Cell surface-bound heat shock protein 70 (Hsp70) mediates perforin-independent apoptosis by specific binding and uptake of granzyme B. J Biol Chem 278: 41173-41181, 2003.

140. Kurschus FC, Bruno R, Fellows E, Falk CS and Jenne DE: Membrane receptors are not required to deliver granzyme B during killer cell attack. Blood 105: 2049-2058, 2005.

141. Hoves S, Trapani JA and Voskoboinik I: The battlefield of perforin/granzyme cell death pathways. J Leukoc Biol 87: 237-243, 2010

142. Masson D and Tschopp J: Isolation of a lytic, pore-forming protein (perforin) from cytolytic T-lymphocytes. J Biol Chem 260: 9069-9072, 1985.

143. Podack ER, Young JD and Cohn ZA: Isolation and biochemical and functional characterization of perforin 1 from cytolytic T-cell granules. Proc Natl Acad Sci USA 82: 8629-8633, 1985.

144. Young JD, Hengartner H, Podack ER and Cohn ZA: Purification and characterization of a cytolytic pore-forming protein from granules of cloned lymphocytes with natural killer activity. Cell 44: 849-859, 1986.

145. Uellner R, Zvelebil MJ, Hopkins J, et al: Perforin is activated by a proteolytic cleavage during biosynthesis which reveals a phospholipid-binding C2 domain. EMBO J 16: 7287-7296, 1997.

146. Kurschus FC, Fellows E, Stegmann E and Jenne DE: Granzyme B delivery via perforin is restricted by size, but not by heparan sulfate-dependent endocytosis. Proc Natl Acad Sci USA 105: 13799-13804, 2008

147. Baran K, Dunstone M, Chia J, et al: The molecular basis for perforin oligomerization and transmembrane pore assembly. Immunity 30: 684-695, 2009.

148. Van Damme P, Maurer-Stroh S, Plasman K, et al: Analysis of protein processing by $\mathrm{N}$-terminal proteomics reveals novel species-specific substrate determinants of granzyme B orthologs. Mol Cell Proteomics 8: 258-272, 2009.

149.Darmon AJ, Nicholson DW and Bleackley RC: Activation of the apoptotic protease CPP32 by cytotoxic T-cell-derived granzyme B. Nature 377: 446-448, 1995.

150. Martin SJ, Amarante-Mendes GP, Shi L, et al: The cytotoxic cell protease granzyme B initiates apoptosis in a cell-free system by proteolytic processing and activation of the ICE/CED-3 family protease, CPP32, via a novel two-step mechanism. EMBO J 15: 2407-2416, 1996.

151. Fernandes-Alnemri T, Armstrong RC, Krebs J, et al: In vitro activation of CPP32 and Mch3 by Mch4, a novel human apoptotic cysteine protease containing two FADD-like domains. Proc Natl Acad Sci USA 93: 7464-7469, 1996.

152. Gu Y, Sarnecki C, Fleming MA, Lippke JA, Bleackley RC and $\mathrm{Su}$ MS: Processing and activation of $\mathrm{CMH}-1$ by granzyme $\mathrm{B}$. J Biol Chem 271: 10816-10820, 1996.

153. Quan LT, Tewari M, O'Rourke K, et al: Proteolytic activation of the cell death protease Yama/CPP32 by granzyme B. Proc Natl Acad Sci USA 93: 1972-1976, 1996.

154. Atkinson EA, Barry M, Darmon AJ, Shostak I, Turner PC, Moyer RW and Bleackley RC: Cytotoxic T lymphocyte-assisted suicide. Caspase 3 activation is primarily the result of the direct action of granzyme B. J Biol Chem 273: 21261-21266, 1998.

155. Metkar SS, Wang B, Ebbs ML, Kim JH, Lee YJ, Raja SM and Froelich CJ: Granzyme B activates procaspase-3 which signals a mitochondrial amplification loop for maximal apoptosis. J Cell Biol 160: 875-885, 2003.

156. Krepela E, Prochazka J, Liu X, Fiala P and Kinkor Z: Increased expression of Apaf- 1 and procaspase- 3 and the functionality of intrinsic apoptosis apparatus in non-small cell lung carcinoma. Biol Chem 385: 153-168, 2004. 
157. Orth K, Chinnaiyan AM, Garg M, Froelich CJ and Dixit VM: The CED-3/ICE-like protease Mch2 is activated during apoptosis and cleaves the death substrate lamin A. J Biol Chem 271: 16443-16446, 1996.

158. Srinivasula SM, Fernandes-Alnemri T, Zangrilli J, et al: The Ced-3/interleukin 1beta converting enzyme-like homolog Mch6 and the lamin-cleaving enzyme Mch2alpha are substrates for the apoptotic mediator CPP32. J Biol Chem 271: 27099-27106, 1996.

159. Duan H, Orth K, Chinnaiyan AM, Poirier GG, Froelich CJ, He WW and Dixit VM: ICE-LAP6, a novel member of the ICE/Ced-3 gene family, is activated by the cytotoxic T cell protease granzyme B. J Biol Chem 271: 16720-16724, 1996.

160. Medema JP, Toes RE, Scaffidi C, et al: Cleavage of FLICE (caspase-8) by granzyme B during cytotoxic T lymphocyteinduced apoptosis. Eur J Immunol 27: 3492-3498, 1997.

161. Talanian RV, Yang X, Turbov J, et al: Granule-mediated killing: pathways for granzyme B-initiated apoptosis. J Exp Med 186: 1323-1331, 1997.

162. Murphy BM, Creagh EM and Martin SJ: Interchain proteolysis, in the absence of a dimerization stimulus, can initiate apoptosisassociated caspase-8 activation. J Biol Chem 279: 36916-36922, 2004.

163. Waterhouse NJ, Sedelies KA and Trapani JA: Role of Bidinduced mitochondrial outer membrane permeabilization in granzyme B-induced apoptosis. Immunol Cell Biol 84: 72-78, 2006.

164. Barry M, Heibein JA, Pinkoski MJ, Lee SF, Moyer RW, Green DR and Bleackley RC: Granzyme B short-circuits the need for caspase 8 activity during granule-mediated cytotoxic T-lymphocyte killing by directly cleaving Bid. Mol Cell Biol 20: $3781-3794,2000$

165. Heibein JA, Goping IS, Barry M, Pinkoski MJ, Shore GC, Green DR and Bleackley RC: Granzyme B-mediated cytochrome c release is regulated by the $\mathrm{Bcl}-2$ family members bid and Bax. J Exp Med 192: 1391-1402, 2000

166. Sutton VR, Davis JE, Cancilla M, et al: Initiation of apoptosis by granzyme B requires direct cleavage of bid, but not direct granzyme B-mediated caspase activation. J Exp Med 192: 1403-1414, 2000

167. Alimonti JB, Shi L, Baijal PK and Greenberg AH: Granzyme B induces BID-mediated cytochrome $\mathrm{c}$ release and mitochondrial permeability transition. J Biol Chem 276: 6974-6982, 2001.

168. Pinkoski MJ, Waterhouse NJ, Heibein JA, et al: Granzyme Bmediated apoptosis proceeds predominantly through a Bcl-2 inhibitable mitochondrial pathway. J Biol Chem 276: 12060-12067, 2001

169. Waterhouse NJ, Sedelies KA, Browne KA, et al: A central role for Bid in granzyme B-induced apoptosis. J Biol Chem 280: 4476-4482, 2005

170.Han J, Goldstein LA, Hou W, Froelich CJ, Watkins SC and Rabinowich H: Deregulation of mitochondrial membrane potential by mitochondrial insertion of granzyme B and direct Hax-1 cleavage. J Biol Chem 285: 22461-22472, 2010.

171. Trapani JA, Browne KA, Smyth MJ and Jans DA: Localization of granzyme B in the nucleus. A putative role in the mechanism of cytotoxic lymphocyte-mediated apoptosis. J Biol Chem 271: 4127-4133, 1996.

172. Jans DA, Jans P, Briggs LJ, Sutton V and Trapani JA: Nuclear transport of granzyme B (fragmentin-2). Dependence of perforin in vivo and cytosolic factors in vitro. J Biol Chem 271: 30781-30789, 1996.

173. Pinkoski MJ, Heibein JA, Barry M and Bleackley RC: Nuclear translocation of granzyme B in target cell apoptosis. Cell Death Differ 7: 17-24, 2000

174. Blink EJ, Jiansheng Z, Hu W, Calanni ST, Trapani JA, Bird PI and Jans DA: Interaction of the nuclear localizing cytolytic granule serine protease granzyme B with importin alpha or beta: modulation by the serpin inhibitor PI-9. J Cell Biochem 95: 598-610, 2005

175. Sharif-Askari E, Alam A, Rheaume E, et al: Direct cleavage of the human DNA fragmentation factor- 45 by granzyme B induces caspase-activated DNase release and DNA fragmentation. EMBO J 20: 3101-3113, 2001

176. Widlak P and Garrard WT: Roles of the major apoptotic nuclease-DNA fragmentation factor-in biology and disease. Cell Mol Life Sci 66: 263-274, 2009.

177. Joseph B, Ekedahl J, Lewensohn R, Marchetti P, Formstecher P and Zhivotovsky B: Defective caspase-3 relocalization in nonsmall cell lung carcinoma. Oncogene 20: 2877-2888, 2001.
178. Ghavami S, Hashemi M, Ande SR, et al: Apoptosis and cancer: mutations within caspase genes. J Med Genet 46: 497-510, 2009.

179. Choy JC, Hung VH, Hunter AL, et al: Granzyme B induces smooth muscle cell apoptosis in the absence of perforin: involvement of extracellular matrix degradation. Arterioscler Thromb Vasc Biol 24: 2245-2250, 2004

180. Buzza MS, Zamurs L, Sun J, et al: Extracellular matrix remodeling by human granzyme B via cleavage of vitronectin, fibronectin, and laminin. J Biol Chem 280: 23549-23558, 2005.

181. Chiarugi P and Giannoni E: Anoikis: a necessary death program for anchorage-dependent cells. Biochem Pharmacol 76: $1352-1364,2008$

182. Hood JD and Cheresh DA: Role of integrins in cell invasion and migration. Nat Rev Cancer 2: 91-100, 2002

183. Simpson CD, Anyiwe K and Schimmer AD: Anoikis resistance and tumor metastasis. Cancer Lett 272: 177-185, 2008.

184. Westhoff MA and Fulda S: Adhesion-mediated apoptosis resistance in cancer. Drug Resist Updat 12: 127-136, 2009.

185. Adrain C, Duriez PJ, Brumatti G, Delivani P and Martin SJ: The cytotoxic lymphocyte protease, granzyme $\mathrm{B}$, targets the cytoskeleton and perturbs microtubule polymerization dynamics. J Biol Chem 281: 8118-8125, 2006.

186. Browne KA, Johnstone RW, Jans DA and Trapani JA: Filamin (280-kDa actin-binding protein) is a caspase substrate and is also cleaved directly by the cytotoxic $\mathrm{T}$ lymphocyte protease granzyme B during apoptosis. J Biol Chem 275: 39262-39266, 2000.

187. Kuwana M, Okano T, Ogawa Y, Kaburaki J and Kawakami Y: Autoantibodies to the amino-terminal fragment of beta-fodrin expressed in glandular epithelial cells in patients with Sjogren's syndrome. J Immunol 167: 5449-5456, 2001.

188. Sebbagh M, Hamelin J, Bertoglio J, Solary E and Breard J: Direct cleavage of ROCK II by granzyme B induces target cell membrane blebbing in a caspase-independent manner. J Exp Med 201: 465-471, 2005

189.Zhang D, Beresford PJ, Greenberg AH and Lieberman J: Granzymes A and B directly cleave lamins and disrupt the nuclear lamina during granule-mediated cytolysis. Proc Natl Acad Sci USA 98: 5746-5751, 2001.

190.Loeb CR, Harris JL and Craik CS: Granzyme B proteolyzes receptors important to proliferation and survival, tipping the balance toward apoptosis. J Biol Chem 281: 28326-28335, 2006.

191. Bredemeyer AJ, Carrigan PE, Fehniger TA, Smith DF and Ley TJ: Hop cleavage and function in granzyme B-induced apoptosis. J Biol Chem 281: 37130-37141, 2006.

192. Caruso JA and Reiners JJ Jr: Proteolysis of HIP during apoptosis occurs within a region similar to the BID loop. Apoptosis 11: 1877-1885, 2006.

193. Hostetter DR, Loeb CR, Chu F and Craik CS: Hip is a prosurvival substrate of granzyme B. J Biol Chem 282: 27865-27874, 2007.

194. Casciola-Rosen L, Garcia-Calvo M, Bull HG, Becker JW, Hines T, Thornberry NA and Rosen A: Mouse and human granzyme B have distinct tetrapeptide specificities and abilities to recruit the Bid pathway. J Biol Chem 282: 4545-4552, 2007.

195. Cullen SP, Adrain C, Luthi AU, Duriez PJ and Martin SJ Human and murine granzyme B exhibit divergent substrate preferences. J Cell Biol 176: 435-444, 2007.

196. Kaiserman D, Bird CH, Sun J, et al: The major human and mouse granzymes are structurally and functionally divergent. J Cell Biol 175: 619-630, 2006

197. Sprecher CA, Morgenstern KA, Mathewes S, Dahlen JR, Schrader SK, Foster DC and Kisiel W: Molecular cloning, expression, and partial characterization of two novel members of the ovalbumin family of serine proteinase inhibitors. J Biol Chem 270: 29854-29861, 1995.

198. Sun J, Bird CH, Sutton V, et al: A cytosolic granzyme B inhibitor related to the viral apoptotic regulator cytokine response modifier A is present in cytotoxic lymphocytes. J Biol Chem 271: 27802-27809, 1996

199. Mahrus S, Kisiel W and Craik CS: Granzyme M is a regulatory protease that inactivates proteinase inhibitor 9 , an endogenous inhibitor of granzyme B. J Biol Chem 279: 54275-54282, 2004.

200. Andrade F, Fellows E, Jenne DE, Rosen A and Young CS: Granzyme $\mathrm{H}$ destroys the function of critical adenoviral proteins required for viral DNA replication and granzyme B inhibition. EMBO J 26: 2148-2157, 2007 
201.Balaji KN, Schaschke N, Machleidt W, Catalfamo M and Henkart PA: Surface cathepsin B protects cytotoxic lymphocytes from self-destruction after degranulation. J Exp Med 196 493-503, 2002.

202. Ray CA, Black RA, Kronheim SR, Greenstreet TA, Sleath PR, Salvesen GS and Pickup DJ: Viral inhibition of inflammation: cowpox virus encodes an inhibitor of the interleukin-1 beta converting enzyme. Cell 69: 597-604, 1992.

203. Quan LT, Caputo A, Bleackley RC, Pickup DJ and Salvesen GS Granzyme B is inhibited by the cowpox virus serpin cytokine response modifier A. J Biol Chem 270: 10377-10379, 1995.

204. Tewari M and Dixit VM: Fas- and tumor necrosis factorinduced apoptosis is inhibited by the poxvirus crmA gene product. J Biol Chem 270: 3255-3260, 1995.

205. Tewari M, Telford WG, Miller RA and Dixit VM: CrmA, a poxvirus-encoded serpin, inhibits cytotoxic T-lymphocytemediated apoptosis. J Biol Chem 270: 22705-22708, 1995.

206. Tewari M, Quan LT, O'Rourke K, et al: Yama/CPP32 beta, a mammalian homolog of CED-3, is a CrmA-inhibitable protease that cleaves the death substrate poly(ADP-ribose) polymerase. Cell 81: 801-809, 1995

207. Swanson R, Raghavendra MP, Zhang W, Froelich C, Gettins PG and Olson ST: Serine and cysteine proteases are translocated to similar extents upon formation of covalent complexes with serpins. Fluorescence perturbation and fluorescence resonance energy transfer mapping of the protease binding site in CrmA complexes with granzyme B and caspase-1. J Biol Chem 282: 2305-2313, 2007

208. Andrade F, Bull HG, Thornberry NA, Ketner GW, CasciolaRosen LA and Rosen A: Adenovirus L4-100K assembly protein is a granzyme B substrate that potently inhibits granzyme Bmediated cell death. Immunity 14: 751-761, 2001.

209. Andrade F, Casciola-Rosen LA and Rosen A: A novel domain in adenovirus $\mathrm{L} 4-100 \mathrm{~K}$ is required for stable binding and efficient inhibition of human granzyme B: possible interaction with a species-specific exosite. Mol Cell Biol 23: 6315-6326, 2003.

210.Law RH, Zhang Q, McGowan S, et al: An overview of the serpin superfamily. Genome Biol 7: 216, 2006.

211. Bots M and Medema JP: Serpins in T cell immunity. J Leukoc Biol 84: 1238-1247, 2008.

212. Remold-O'Donnell E: The ovalbumin family of serpin proteins. FEBS Lett 315: 105-108, 1993.

213. Bird CH, Sutton VR, Sun J, et al: Selective regulation of apoptosis: the cytotoxic lymphocyte serpin proteinase inhibitor 9 protects against granzyme B-mediated apoptosis without perturbing the Fas cell death pathway. Mol Cell Biol 18: 6387-6398, 1998

214. Hirst CE, Buzza MS, Bird CH, et al: The intracellular granzyme B inhibitor, proteinase inhibitor 9, is up-regulated during accessory cell maturation and effector cell degranulation, and its overexpression enhances CTL potency. J Immunol 170: $805-815,2003$

215. Coughlin P, Nicholl J, Sun J, Salem H, Bird P and Sutherland GR: Chromosomal mapping of the human proteinase inhibitor 6 (PI6) gene to $6 \mathrm{p} 25$ by fluorescence in situ hybridization. Genomics 26: 431-433, 1995 .

216. Evans E, Cooley J and Remold-O'Donnell E: Characterization and chromosomal localization of ELANH2, the gene encoding human monocyte/neutrophil elastase inhibitor. Genomics 28 $235-240,1995$.

217.Eyre HJ, Sun J, Sutherland GR and Bird P: Chromosomal mapping of the gene (PI9) encoding the intracellular serpin proteinase inhibitor 9 to $6 \mathrm{p} 25$ by fluorescence in situ hybridization. Genomics 37: 406-408, 1996.

218. Scott FL, Coughlin PB, Bird C, Cerruti L, Hayman JA and Bird P: Proteinase inhibitor 6 cannot be secreted, which suggests it is a new type of cellular serpin. J Biol Chem 271: 1605-1612, 1996.

219. Sun J, Stephens R, Mirza G, Kanai H, Ragoussis J and Bird PI: A serpin gene cluster on chromosome $6 \mathrm{p} 25$ contains PI6, PI9 and ELANH2 which have a common structure almost identical to the $18 \mathrm{q} 21$ ovalbumin serpin genes. Cytogenet Cell Genet 82: 273-277, 1998.

220. Silverman GA, Whisstock JC, Askew DJ, et al: Human clade B serpins (ov-serpins) belong to a cohort of evolutionarily dispersed intracellular proteinase inhibitor clades that protect cells from promiscuous proteolysis. Cell Mol Life Sci 61: 301-325, 2004.
221.Bladergroen BA, Strik MC, Bovenschen N, et al: The granzyme B inhibitor, protease inhibitor 9 , is mainly expressed by dendritic cells and at immune-privileged sites. J Immunol 166: 3218-3225, 2001

222. Ida H, Nakashima T, Kedersha NL, et al: Granzyme B leakageinduced cell death: a new type of activation-induced natural killer cell death. Eur J Immunol 33: 3284-3292, 2003.

223. Classen CF, Bird PI and Debatin KM: Modulation of the granzyme $\mathrm{B}$ inhibitor proteinase inhibitor 9 (PI-9) by activation of lymphocytes and monocytes in vitro and by Epstein-Barr virus and bacterial infection. Clin Exp Immunol 143: 534-542, 2006.

224. Bladergroen BA, Strik MC, Wolbink AM, Wouters D, Broekhuizen R, Kummer JA and Hack CE: The granzyme B inhibitor proteinase inhibitor 9 (PI9) is expressed by human mast cells. Eur J Immunol 35: 1175-1183, 2005

225. Buzza MS, Hirst CE, Bird CH, Hosking P, McKendrick J and Bird PI: The granzyme B inhibitor, PI-9, is present in endothelial and mesothelial cells, suggesting that it protects bystander cells during immune responses. Cell Immunol 210: $21-29,2001$

226. Young JL, Sukhova GK, Foster D, Kisiel W, Libby P and Schonbeck U: The serpin proteinase inhibitor 9 is an endogenous inhibitor of interleukin 1beta-converting enzyme (caspase-1) activity in human vascular smooth muscle cells. J Exp Med 191: 1535-1544, 2000.

227. Bots M, De Bruin E, Rademaker-Koot MT and Medema JP: Proteinase inhibitor-9 expression is induced by maturation in dendritic cells via p38 MAP kinase. Hum Immunol 68: 959-964, 2007.

228. Buzza MS, Hosking P and Bird PI: The granzyme B inhibitor, PI-9, is differentially expressed during placental development and up-regulated in hydatidiform moles. Placenta 27: 62-69, 2006.

229. Medema JP, De Jong J, Peltenburg LT, et al: Blockade of the granzyme $\mathrm{B} /$ perforin pathway through overexpression of the serine protease inhibitor PI-9/SPI-6 constitutes a mechanism for immune escape by tumors. Proc Natl Acad Sci USA 98: $11515-11520,2001$

230. Oudejans JJ, Harijadi H, Kummer JA, et al: High numbers of granzyme $\mathrm{B} / \mathrm{CD} 8$-positive tumour-infiltrating lymphocytes in nasopharyngeal carcinoma biopsies predict rapid fatal outcome in patients treated with curative intent. J Pathol 198: 468-475, 2002.

231. Tanaka K, Harashima N, Niiya F, et al: Serine proteinase inhibitor 9 can be recognized by cytotoxic $\mathrm{T}$ lymphocytes of epithelial cancer patients. Jpn J Cancer Res 93: 198-208, 2002.

232. Van Houdt IS, Oudejans JJ, van den Eertwegh AJ, et al: Expression of the apoptosis inhibitor protease inhibitor 9 predicts clinical outcome in vaccinated patients with stage III and IV melanoma. Clin Cancer Res 11: 6400-6407, 2005.

233. Majima T, Ichikura T, Chochi K, et al: Exploitation of interleukin-18 by gastric cancers for their growth and evasion of host immunity. Int J Cancer 118: 388-395, 2006.

234. Bird CH, Blink EJ, Hirst CE, et al: Nucleocytoplasmic distribution of the ovalbumin serpin PI-9 requires a nonconventional nuclear import pathway and the export factor Crm1. Mol Cell Biol 21: 5396-5407, 2001

235. Rodriguez JA, Span SW, Kruyt FA and Giaccone G: Subcellular localization of CrmA: identification of a novel leucinerich nuclear export signal conserved in anti-apoptotic serpins. Biochem J 373: 251-259, 2003

236. Kannan-Thulasiraman P and Shapiro DJ: Modulators of inflammation use nuclear factor-kappa B and activator protein-1 sites to induce the caspase-1 and granzyme B inhibitor, proteinase inhibitor 9. J Biol Chem 277: 41230-41239, 2002.

237. Barrie MB, Stout HW, Abougergi MS, Miller BC and Thiele DL: Antiviral cytokines induce hepatic expression of the granzyme B inhibitors, proteinase inhibitor 9 and serine proteinase inhibitor 6 . J Immunol 172: 6453-6459, 2004.

238. Horie O, Saigo K, Murayama T and Ryo R: Differential expression of proteinase inhibitor-9 and granzyme B mRNAs in activated immunocompetent cells. Tohoku J Exp Med 205: 103-113, 2005

239. Kanamori H, Krieg S, Mao C, Di Pippo VA, Wang S, Zajchowski DA and Shapiro DJ: Proteinase inhibitor 9, an inhibitor of granzyme B-mediated apoptosis, is a primary estrogen-inducible gene in human liver cells. J Biol Chem 275: $5867-5873,2000$. 
240. Krieg AJ, Krieg SA, Ahn BS and Shapiro DJ: Interplay between estrogen response element sequence and ligands controls in vivo binding of estrogen receptor to regulated genes. J Biol Chem 279: 5025-5034, 2004

241.Jiang X, Orr BA, Kranz DM and Shapiro DJ: Estrogen induction of the granzyme B inhibitor, proteinase inhibitor 9 , protects cells against apoptosis mediated by cytotoxic $\mathrm{T}$ lymphocytes and natural killer cells. Endocrinology 147: 1419-1426, 2006.

242.Jiang X, Ellison SJ, Alarid ET and Shapiro DJ: Interplay between the levels of estrogen and estrogen receptor controls the level of the granzyme inhibitor, proteinase inhibitor 9 and susceptibility to immune surveillance by natural killer cells. Oncogene 26: 4106-4114, 2007.

243. Jiang X, Patterson NM, Ling Y, Xie J, Helferich WG and Shapiro DJ: Low concentrations of the soy phytoestrogen genistein induce proteinase inhibitor 9 and block killing of breast cancer cells by immune cells. Endocrinology 149: 5366-5373, 2008

244. Krieg SA, Krieg AJ and Shapiro DJ: A unique downstream estrogen responsive unit mediates estrogen induction of proteinase inhibitor-9, a cellular inhibitor of IL-1beta-converting enzyme (caspase 1). Mol Endocrinol 15: 1971-1982, 2001.

245. Ten Berge RL, Meijer CJ, Dukers DF, et al: Expression levels of apoptosis-related proteins predict clinical outcome in anaplastic large cell lymphoma. Blood 99: 4540-4546, 2002.

246. Cunningham TD, Jiang X and Shapiro DJ: Expression of high levels of human proteinase inhibitor 9 blocks both perforin/ granzyme and Fas/Fas ligand-mediated cytotoxicity. Cell Immunol 245: 32-41, 2007.

247. Kummer JA, Micheau O, Schneider P, et al: Ectopic expression of the serine protease inhibitor PI9 modulates death receptormediated apoptosis. Cell Death Differ 14: 1486-1496, 2007

248. Hill RM, Morresey KS, Coates LC, et al: A new intracellular serine protease inhibitor expressed in the rat pituitary gland complexes with granzyme B. FEBS Lett 440: 361-364, 1998.

249. Fell B, Smith AM, Hill RM, Parmar PK, Coates LC, Mezey E and Birch NP: Characterisation of two serine protease inhibitors expressed in the pituitary gland. Arch Physiol Biochem 110: $26-33,2002$

250. Sipione S, Simmen KC, Lord SJ, et al: Identification of a novel human granzyme B inhibitor secreted by cultured sertoli cells. J Immunol 177: 5051-5058, 2006.

251. Friedman M and Stahl S: Engineered affinity proteins for tumour-targeting applications. Biotechnol Appl Biochem 53: $1-29,2009$.

252. Kurschus FC and Jenne DE: Delivery and therapeutic potential of human granzyme B. Immunol Rev 235: 159-171, 2010.

253. Kruser TJ and Wheeler DL: Mechanisms of resistance to HER family targeting antibodies. Exp Cell Res 316: 1083-1100, 2010.

254.Zhao J, Zhang LH, Jia LT, et al: Secreted antibody/granzyme B fusion protein stimulates selective killing of HER2-overexpressing tumor cells. J Biol Chem 279: 21343-21348, 2004.

255.Zhang L, Zhao J, Wang T, et al: HER2-targeting recombinant protein with truncated pseudomonas exotoxin A translocation domain efficiently kills breast cancer cells. Cancer Biol Ther 7: 1226-1231, 2008.

256. Dalken B, Giesubel U, Knauer SK and Wels WS: Targeted induction of apoptosis by chimeric granzyme B fusion proteins carrying antibody and growth factor domains for cell recognition. Cell Death Differ 13: 576-585, 2006.

257. Liu Y, Cheung LH, Thorpe P and Rosenblum MG: Mechanistic studies of a novel human fusion toxin composed of vascular endothelial growth factor (VEGF)121 and the serine protease granzyme B: directed apoptotic events in vascular endothelial cells. Mol Cancer Ther 2: 949-959, 2003.

258. Liu Y, Cheung LH, Hittelman WN and Rosenblum MG: Targeted delivery of human pro-apoptotic enzymes to tumor cells: in vitro studies describing a novel class of recombinant highly cytotoxic agents. Mol Cancer Ther 2: 1341-1350, 2003.

259. Kurschus FC, Kleinschmidt M, Fellows E, Dornmair K, Rudolph R, Lilie $\mathrm{H}$ and Jenne DE: Killing of target cells by redirected granzyme $\mathrm{B}$ in the absence of perforin. FEBS Lett 562: 87-92, 2004.

260. Stahnke B, Thepen T, Stocker M, et al: Granzyme B-H22(scFv), a human immunotoxin targeting CD64 in acute myeloid leukemia of monocytic subtypes. Mol Cancer Ther 7: 2924-2932, 2008
261.Li R, Ruttinger D, Urba W, Fox BA and Hu HM: Targeting and amplification of immune killing of tumor cells by proSmac. Int J Cancer 109: 85-94, 2004.

262. Caldas H, Jaynes FO, Boyer MW, Hammond S and Altura RA Survivin and granzyme B-induced apoptosis, a novel anticancer therapy. Mol Cancer Ther 5: 693-703, 2006.

263. Elsner L, Flugge PF, Lozano J, et al: The endogenous danger signals HSP70 and MICA cooperate in the activation of cytotoxic effector functions of NK cells. J Cell Mol Med 14: 992-1002, 2010.

264. Sharma S, Kelly TK and Jones PA: Epigenetics in cancer. Carcinogenesis 31: 27-36, 2010.

265. Harvey NL, Trapani JA, Fernandes-Alnemri T, Litwack G, Alnemri ES and Kumar S: Processing of the Nedd2 precursor by ICE-like proteases and granzyme B. Genes Cells 1: 673-685, 1996.

266. Casciola-Rosen L, Miagkov A, Nagaraju K, Askin F, Jacobson L, Rosen A and Drachman DB: Granzyme B: evidence for a role in the origin of myasthenia gravis. J Neuroimmunol 201-202: $33-40,2008$

267.Hansen MH, Nielsen H and Ditzel HJ: The tumor-infiltrating $\mathrm{B}$ cell response in medullary breast cancer is oligoclonal and directed against the autoantigen actin exposed on the surface of apoptotic cancer cells. Proc Natl Acad Sci USA 98: 12659-12664, 2001.

268. Bredemeyer AJ, Townsend RR and Ley TJ: Use of protease proteomics to discover granzyme B substrates. Immunol Res 32: 143-154, 2005

269. Casciola-Rosen L, Andrade F, Ulanet D, Wong WB and Rosen A: Cleavage by granzyme B is strongly predictive of autoantigen status: implications for initiation of autoimmunity. J Exp Med 190: 815-826, 1999

270. Li H, Zhu H, Xu CJ and Yuan J: Cleavage of BID by caspase 8 mediates the mitochondrial damage in the Fas pathway of apoptosis. Cell 94: 491-501, 1998.

271. Ulanet DB, Torbenson M, Dang CV, Casciola-Rosen L and Rosen A: Unique conformation of cancer autoantigen B23 in hepatoma: a mechanism for specificity in the autoimmune response. Proc Natl Acad Sci USA 100: 12361-12366, 2003.

272. Ulanet DB, Flavahan NA, Casciola-Rosen L and Rosen A: Selective cleavage of nucleolar autoantigen B23 by granzyme B in differentiated vascular smooth muscle cells: insights into the association of specific autoantibodies with distinct disease phenotypes. Arthritis Rheum 50: 233-241, 2004.

273. Muzio M, Chinnaiyan AM, Kischkel FC, et al: FLICE, a novel FADD-homologous ICE/CED-3-like protease, is recruited to the CD95 (Fas/APO-1) death-inducing signaling complex. Cell 85: 817-827, 1996

274. Wieckowski E, Wang GQ, Gastman BR, Goldstein LA and Rabinowich H: Granzyme B-mediated degradation of T-cell receptor zeta chain. Cancer Res 62: 4884-4889, 2002.

275. Schachna L, Wigley FM, Morris S, Gelber AC, Rosen A and Casciola-Rosen L: Recognition of granzyme B-generated autoantigen fragments in scleroderma patients with ischemic digital loss. Arthritis Rheum 46: 1873-1884, 2002.

276. Andrade F, Roy S, Nicholson D, Thornberry N, Rosen A and Casciola-Rosen L: Granzyme B directly and efficiently cleaves several downstream caspase substrates: implications for CTLinduced apoptosis. Immunity 8: 451-460, 1998.

277. Nagaraju K, Cox A, Casciola-Rosen L and Rosen A: Novel fragments of the Sjogren's syndrome autoantigens alpha-fodrin and type 3 muscarinic acetylcholine receptor generated during cytotoxic lymphocyte granule-induced cell death. Arthritis Rheum 44: 2376-2386, 2001.

278. Levine SM, Raben N, Xie D, et al: Novel conformation of histidyl-transfer RNA synthetase in the lung: the target tissue in Jo-1 autoantibody-associated myositis. Arthritis Rheum 56: 2729-2739, 2007.

279. Thomas DA, Du C, Xu M, Wang X and Ley TJ: DFF45/ICAD can be directly processed by granzyme $\mathrm{B}$ during the induction of apoptosis. Immunity 12: 621-632, 2000.

280. Gahring L, Carlson NG, Meyer EL and Rogers SW: Granzyme B proteolysis of a neuronal glutamate receptor generates an autoantigen and is modulated by glycosylation. J Immunol 166: 1433-1438, 2001.

281. Froelich CJ, Hanna WL, Poirier GG, et al: Granzyme B/perforinmediated apoptosis of Jurkat cells results in cleavage of poly (ADP-ribose) polymerase to the $89-\mathrm{kDa}$ apoptotic fragment and less abundant 64-kDa fragment. Biochem Biophys Res Commun 227: 658-665, 1996. 
282. Matsumura S, van De WJ, Kita H, et al: Contribution to antimitochondrial antibody production: cleavage of pyruvate dehydrogenase complex-E2 by apoptosis-related proteases. Hepatology 35: 14-22, 2002.

283. Mahoney JA, Odin JA, White SM, Shaffer D, Koff A, Casciola-Rosen L and Rosen A: The human homologue of the yeast polyubiquitination factor Ufd2p is cleaved by caspase 6 and granzyme B during apoptosis. Biochem J 361: 587-595, 2002 .
284.Lee KJ, Dong X, Wang J, Takeda Y and Dynan WS : Identification of human autoantibodies to the DNA ligase IV/ XRCC4 complex and mapping of an autoimmune epitope to a potential regulatory region. J Immunol 169: 3413-3421, 2002.

285. Gervais FG, Thornberry NA, Ruffolo SC, Nicholson DW and Roy S: Caspases cleave focal adhesion kinase during apoptosis to generate a FRNK-like polypeptide. J Biol Chem 273: 17102-17108, 1998. 